\title{
Diffusion-driven chromium isotope fractionation in ultramafic cumulate minerals: Elemental and isotopic evidence from the Stillwater Complex
}

\author{
Yang Bai ${ }^{\text {a,b,c,*, }}$ Ben-Xun $\mathrm{Su}^{\mathrm{a}, \mathrm{b}, *}$, Yan Xiao ${ }^{\mathrm{d}}$, Chen Chen ${ }^{\mathrm{a}, \mathrm{b}}$, Meng-Meng Cui ${ }^{\mathrm{b}, \mathrm{e}}$, \\ Xiao-Qing $\mathrm{He}^{\mathrm{f}}$, Li-Ping Qin ${ }^{\mathrm{f}}$, Bernard Charlier ${ }^{\mathrm{c}}$ \\ ${ }^{a}$ Key Laboratory of Mineral Resources, Institute of Geology and Geophysics, Chinese Academy of Sciences, P.O. Box 9825, Beijing \\ 100029, China \\ ${ }^{\mathrm{b}}$ University of Chinese Academy of Sciences, Beijing 100049, China \\ ${ }^{\mathrm{c}}$ Department of Geology, University of Liege, B-4000 Liege, Belgium \\ ${ }^{\mathrm{d}}$ State Key Laboratory of Lithospheric Evolution, Institute of Geology and Geophysics, Chinese Academy of Sciences, P.O. Box 9825, \\ Beijing 100029, China \\ ${ }^{\mathrm{e}}$ Key Laboratory of Comprehensive and Highly Efficient Utilization of Salt Lake Resources, Qinghai Institute of Salt Lakes, Chinese Academy \\ of Sciences, Xining 810008, China \\ ${ }^{\mathrm{f}}$ CAS Key Laboratory of Crust-Mantle Materials and Environments, School of Earth and Space Sciences, University of Science and \\ Technology of China, Hefei 230026, China
}

Received 23 January 2019; accepted in revised form 25 July 2019; Available online 2 August 2019

\begin{abstract}
To investigate chromium diffusion kinetics in ultramafic cumulate minerals, we analyzed the $\mathrm{Cr}$ elemental and isotopic compositions of olivine, orthopyroxene, and chromite from the Stillwater layered intrusion. Core-to-rim compositional profiles reveal that $\mathrm{Cr}$ elemental concentrations decrease from 60 to $20 \mathrm{ppm}$ in olivine and from 5000-4600 to 2700-2400 ppm in orthopyroxene. These zoned $\mathrm{Cr}$ distributions in olivine and orthopyroxene suggest that $\mathrm{Cr}$ was lost by diffusion into the melt. Olivine and orthopyroxene have $\delta^{53} \mathrm{Cr}$ values ranging from -0.09 to $0.25 \%$ and from -0.11 to $0.07 \%$, respectively, higher than the values of coexisting chromite $(-0.23$ to $-0.07 \%$ ). This isotopic disequilibrium can be explained by diffusion-driven kinetic fractionation during cooling. The preferential diffusion of light $\mathrm{Cr}$ isotopes from silicate minerals to the melt resulted in isotopically heavier olivine and orthopyroxene, but the kinetic diffusion between chromite and melt negligibly affected the isotopic compositions of chromite grains due to their high $\mathrm{Cr}$ concentrations. Modeling results based on the observed $\mathrm{Cr}$ contents and isotopic compositions of silicate minerals constrain the cooling time of the Peridotite Zone in the Stillwater magmatic system to have been $10-100 \mathrm{kyr}$.
\end{abstract}

(c) 2019 Elsevier Ltd. All rights reserved.

Keywords: Chromium isotopes; Stillwater Complex; Diffusion

\section{INTRODUCTION}

* Corresponding authors at: Key Laboratory of Mineral Resources, Institute of Geology and Geophysics, Chinese Academy of Sciences, P.O. Box 9825, Beijing 100029, China.

E-mail addresses: by@mail.igcas.ac.cn (Y. Bai), subenxun@, mail.igcas.ac.cn (B.-X. Su).
Olivine and pyroxene are the most common silicate minerals in the lithospheric mantle (generally up to $>90 \%$ ), commonly coexisting with chromite in mafic-ultramafic complexes such as layered intrusions and ophiolites, the 
major hosts of $\mathrm{Cr}$ resources on Earth. The kinetics of $\mathrm{Cr}$ volume diffusion in olivine (Ito and Ganguly, 2006; Jollands et al., 2017), pyroxene (Ganguly et al., 2007), and chromite (Suzuki et al., 2008; Posner et al., 2016) have been well-documented. Cr diffusion kinetics can yield timescales of magmatic processes and can be used to determine the closure temperatures of the ${ }^{53} \mathrm{Mn}-{ }^{53} \mathrm{Cr}$ radiogenic dating system (e.g., Ito and Ganguly, 2006; Ganguly et al., 2007). However, the diffusive behavior of $\mathrm{Cr}$ between mineral and melt (mineral to melt or vice versa), the extent of reequilibration, and isotopic fractionation during diffusion are poorly documented. Indeed, both increasing and decreasing core-to-rim $\mathrm{Cr}$ zonation patterns have been observed in silicate minerals (Milman-Barris et al., 2008; Foley et al., 2011; Prelević et al., 2013; Bai et al., 2018). The diffusion of $\mathrm{Cr}$ from melt to coexisting silicate minerals is supported by observed concentration gradients in minerals (e.g., Drake et al., 1989; Ohtani et al., 1989), whereas the opposite case is supported by silicate-melt $\mathrm{Cr}$ partition coefficients that decrease with decreasing temperature or pressure (e.g., Herzberg and O'Hara, 2002).

Recently, high-precision $\mathrm{Cr}$ isotopic analytical techniques have been developed using the double-spike method, thermal ionization mass spectrometry (TIMS), and multicollector inductively coupled plasma mass spectrometry (MC-ICP-MS) (see review by Qin and Wang, 2017), revealing that significant $\mathrm{Cr}$ isotopic fractionations occur during high-temperature geological processes. Farkaš et al. (2013) and Shen et al. (2015) first observed that mantlederived chromite grains were isotopically heavier than the average bulk silicate earth (BSE) and ultramafic rocks, suggesting a potential $\mathrm{Cr}$ isotopic fractionation during chromite crystallization.Xia et al. (2017) reported significant $\mathrm{Cr}$ isotopic variations among globally distributed mantle peridotite xenoliths and Hawaii basalts, implying that $\mathrm{Cr}$ isotopes are fractionated during mantle partial melting and metasomatism. Bonnand et al. (2016) observed considerable $\mathrm{Cr}$ isotope fractionation in lunar basalts, which is interpreted as a resulte of the crystallization of pyroxene and spinel. Recently, Shen et al. (2018) revealed intermineral equilibrium $\mathrm{Cr}$ isotope fractionations in mantle xenoliths.

This study aims to determine the relative role of equilibrium and diffusion-driven fractionations in producing $\mathrm{Cr}$ isotopic variations based on new data from ultramafic cumulates of the Stillwater Complex. Large layered maficultramafic intrusions represent critical links in the differentiation of basaltic magma derived by partial melting of the mantle (Helz, 1995), and are expected to show undifferentiated stable isotopic compositions (e.g., Liu et al., 2014; Chen et al., 2014, 2018). Compared to other maficultramafic rock suites, the evolution and differentiation of large layered intrusions are stratigraphically well defined (e.g., Maier et al., 2012; Charlier et al., 2015; Jenkins and Mungall, 2018). Mineral compositional variations are well documented; they are predominantly controlled by fractional crystallization and are modified by reequilibration with trapped liquids and subsolidus elemental diffusion (Jackson, 1961; Roeder et al., 1979; McCallum, 1996). Therefore, silicate minerals in layered intrusions are suit- able for studying diffusion-driven stable isotopic fractionations (e.g., Liu et al., 2014; Chen et al., 2014, 2018).

Here we present $\mathrm{Cr}$ elemental zoning profiles and isotopic compositions in silicate mineral separates (olivine and orthopyroxene) from the Stillwater Complex, one of the most representative large layered intrusions with world-class chromium deposits (Hess and Smith, 1960; Jackson, 1961; McCallum, 1996). We also analyzed the $\mathrm{Cr}$ isotopic compositions of chromite separates to explore the factors controlling inter-mineral $\mathrm{Cr}$ isotope fractionation. Finally, we use the elemental and isotopic variations induced by $\mathrm{Cr}$ diffusion to constrain the cooling timescale of the Peridotite Zone of the Stillwater Complex.

\section{GEOLOGY OF THE STILLWATER COMPLEX}

The Stillwater Complex is a steeply dipping sub-volcanic intrusion that crops out on the northwestern margin of the Wyoming Craton (McCallum, 1996), covering an area of $180 \mathrm{~km}^{2}$ (Fig. 1a). It intruded Archean metasedimentary rocks (Labotka and Kath, 2001), and was overlain by Paleozoic and Mesozoic sedimentary rocks (Fig. 1b). Zircon U$\mathrm{Pb}$ ages of the complex range from 2712.24 \pm 0.63 (Basal Series) to $2709.11 \pm 0.56 \mathrm{Ma}$ (Banded Series), indicating persistent magma upwelling and emplacement (Wall et al., 2018). The mineralogy, petrology, and geochemistry of the Stillwater Complex are well documented and have been abundantly reviewed (e.g., Hess and Smith, 1960; Jackson, 1961; McCallum, 1996). Three rock series have been described from the bottom to the top of the complex (Fig. 1c). (1) The Basal Series is an irregular sheet-like body dominated by bronzitite with subordinate norite- and sulfide-bearing assemblages and containing xenoliths of cordierite-pyroxene hornfels. A sill/dike suite includes discontinuous sills and dikes of diabase, mafic norite, and massive $\mathrm{Fe}-\mathrm{Ni}-\mathrm{Cu}$ sulfide that intruded metasedimentary rocks beneath the complex (Page, 1979). (2) The Ultramafic Series is subdivided into the upper Bronzitite Zone and lower Peridotite Zone. The Bronzitite Zone is a generally uniform bronzitite with minor interstitial plagioclase and augite. The Peridotite Zone is comprised of a cyclic succession of dunite to granular harzburgite to bronzitite (Jackson, 1961). Chromite seams a few centimeters to $\sim 1 \mathrm{~m}$ thick occur in some of the cyclic units, dominating most of the $\mathrm{Cr}$ resource of the Stillwater Complex, and are commonly sandwiched between underlying cumulus piles and overlying poikilitic harzburgites (Jackson, 1961; Kaufmann et al., 2018). (3) The Banded Series comprises cyclic inch-scale units of norite, gabbronorite, and/or anorthosite, and is subdivided into the Lower, Middle, and Upper subseries (Fig. 1c). Cumulus plagioclase is a major constituent in this series (McCallum, 1996).

The Stillwater Complex hosts world-class reserves of platinum-group elements and $80 \%$ of the $\mathrm{Cr}$ resources of the United States. The main chromite seams, referred to as A through $\mathrm{K}$, are within the Ultramafic Series, and the representative deposits were mined in the Benbow area and Mountain View, which are mainly restricted to the B and G seams, respectively (e.g., Hess and Smith, 1960; Jackson, 1961). Typical chromitites exhibit massive or 

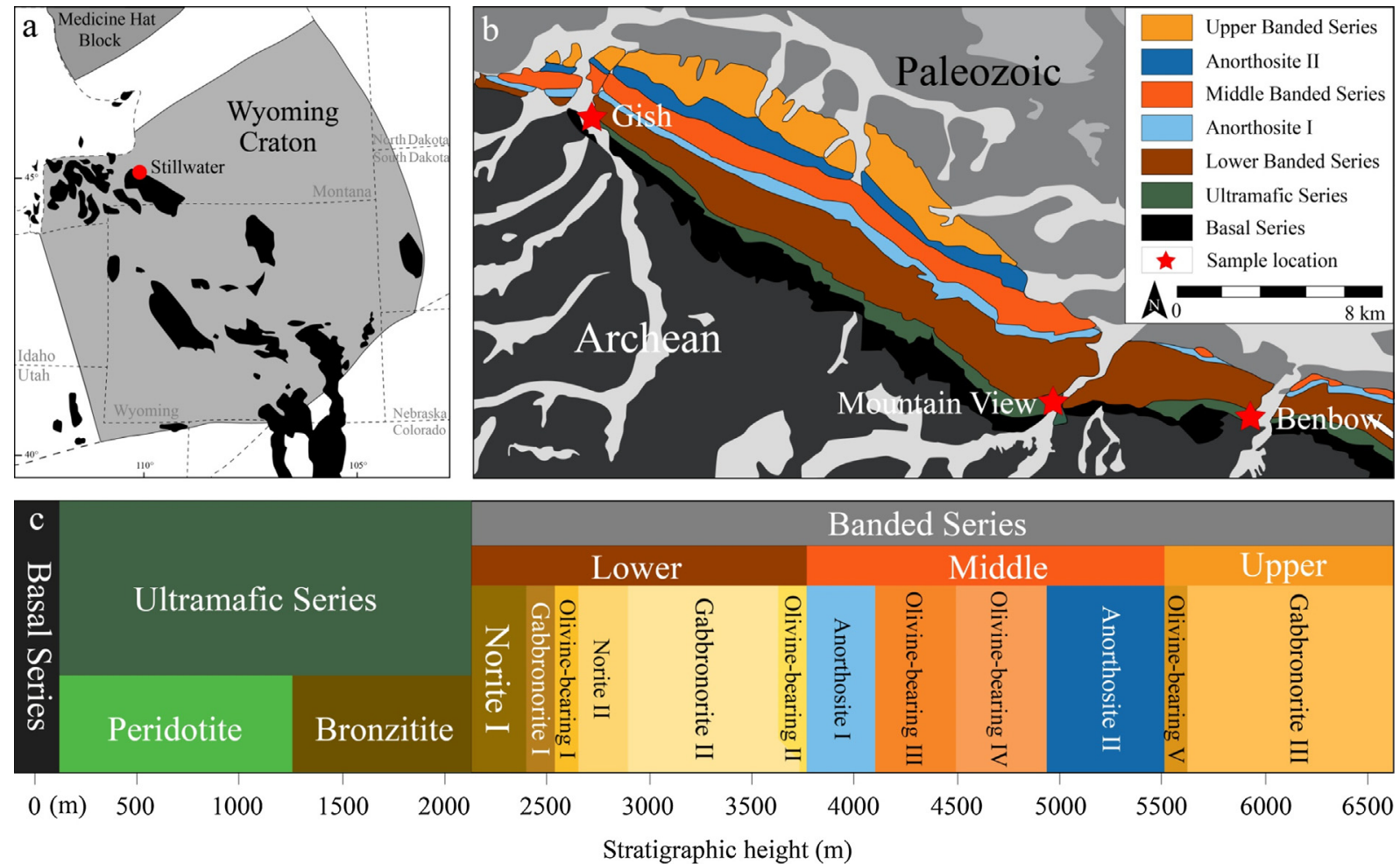

Fig. 1. (a) Location map of the Stillwater Complex in the northwestern part of the Wyoming Craton (gray) in southwestern Montana (USA). Exposures of Precambrian basement are shown black. (b) Generalized geologic map of the Stillwater Complex, with major subdivisions and adjacent rocks (after McCallum, 1996). Red stars show sampling locations within the Peridotite Zone discussed in this study. (c) Composite stratigraphic column showing the lithologic series and zones of the Stillwater Complex (after McCallum, 1996).
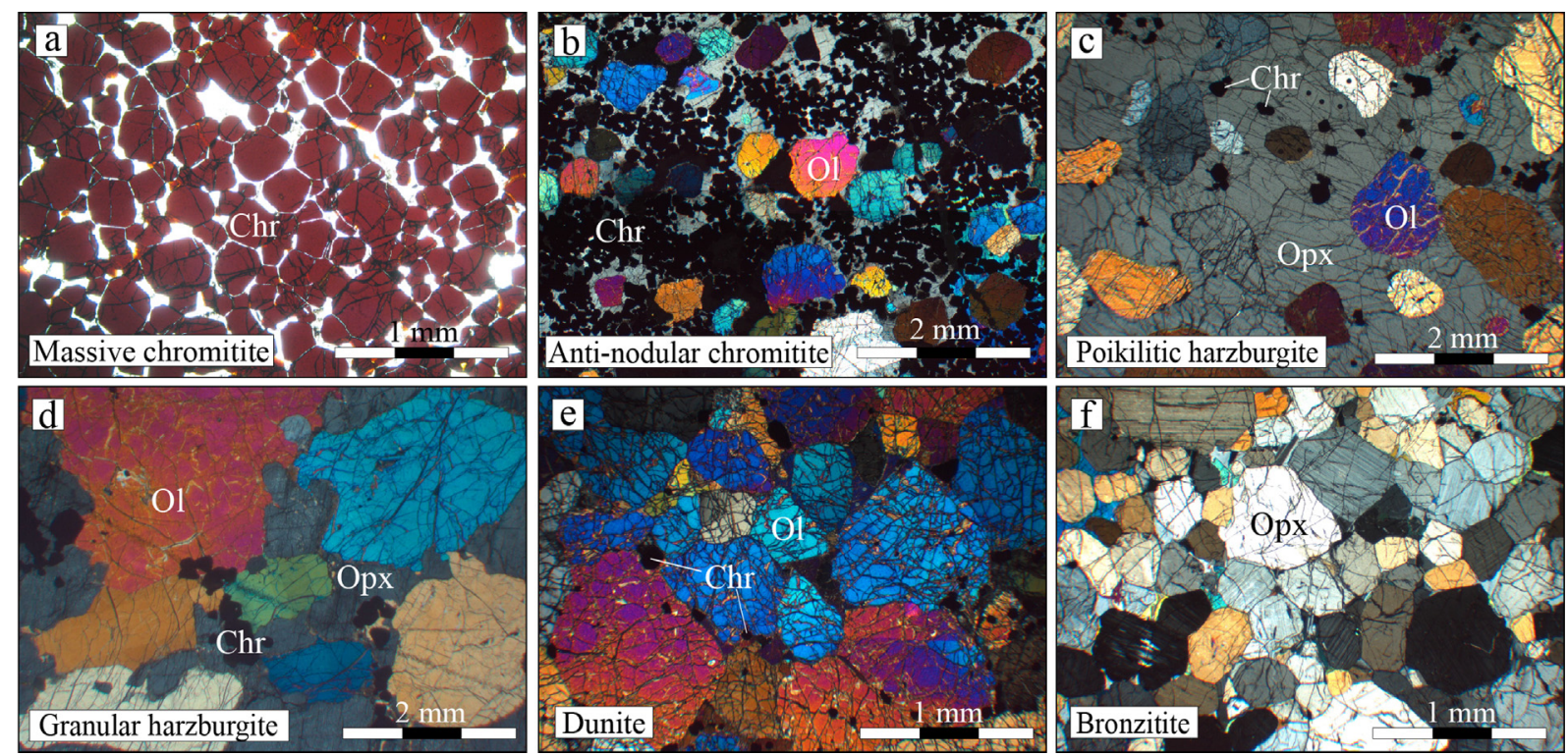

Fig. 2. Plane- (a) and cross-polarized optical images (b-f) of sample thin sections: (a) massive chromitite, (b) anti-nodular chromitite, (c) poikilitic harzburgite, and (d-f) silicate cumulates containing sparse chromite. Abbreviations: olivine (Ol), orthopyroxene (Opx), chromite (Chr).

anti-nodular textures. Massive chromitites are characterized by high proportions $(>80 \mathrm{vol} \%$ ) of coarse-grained granular chromite with interstitial silicate minerals
$(<20 \mathrm{vol} \%$ ) (Fig. 2a). Anti-nodular chromitites are characterized by poikilitic orthopyroxene outlining the boundaries of cumulus olivine grains (Fig. 2b), and a smaller fraction 
of chromite grains $(30-80 \mathrm{vol} \%)$ are randomly distributed within the orthopyroxenes (Jackson, 1961). The massive and anti-nodular chromitites grade to disseminated chromitite with decreased chromite proportions of $10-30 \mathrm{vol} \%$. Subsequently, the proportion of chromite further decreases from the uppermost part of the chromitites into the hanging poikilitic harzburgite (Fig. 2c), which marks the transition between chromitites and silicate cumulates with poikilitic textures similar to the chromitites but chromite contents $(1-10 \mathrm{vol} \%)$ similar to the silicate cumulates. The contact between poikilitic harzburgite and the overlying granular harzburgite is marked by an abrupt change from poikilitic to equigranular orthopyroxene textures (Fig. 2d), and the contact between them is commonly irregular, forming local intersections. Centimeter-scale layering in the granular harzburgite alternates between olivine- or orthopyroxenerich layers, forming the different types of silicate cumulates found in the Peridotite Zone (Fig. 2e,f).

Chromite grains in massive and anti-nodular chromitites have the greatest $\mathrm{MgO}(10.1-12.7 \mathrm{wt} \%)$ and $\mathrm{Cr}_{2} \mathrm{O}_{3}$ contents (42.4-48.6 wt $\%)$ and the lowest $\mathrm{Al}_{2} \mathrm{O}_{3}(16.2-20.5 \mathrm{wt} \%)$ and $\mathrm{FeO}$ contents (21.1-27.3 wt \%). Conversely, chromite grains in silicate-dominated cumulates have the greatest $\mathrm{Al}_{2} \mathrm{O}_{3}$ (17.7-22.6 wt $\%)$ and $\mathrm{FeO}$ contents (22.1-40.0 wt \%) and the lowest $\mathrm{MgO}(6.93-10.2 \mathrm{wt} \%)$ and $\mathrm{Cr}_{2} \mathrm{O}_{3}$ contents (35.7-46.8 wt\%) (Campbell and Murck, 1993). The most magnesian olivine $\left(\mathrm{Fo}_{87.8-89.9}\right)$ and orthopyroxene $\left(\mathrm{Mg} \#_{88.2-90.0}\right)$ occur in massive and anti-nodular chromitites, whereas more Fe-rich olivine $\left(\mathrm{Fo}_{82.8-86.4}\right)$ and orthopyroxene $\left(\mathrm{Mg}_{84.6-86.8}\right)$ occur in the silicatedominated cumulates (e.g., Jackson, 1961; Raedeke and McCallum, 1984; McCallum, 1996). The high Mg\# of silicates in the massive and anti-nodular chromitites have been suggested to result from significant elemental diffusion between the silicate minerals and chromite, with $\mathrm{Mg}$ diffusing from chromite to silicate minerals and Fe diffusing from silicate minerals to chromite (Jackson, 1961; Roeder et al., 1979). As the effect of elemental diffusion depends on the modal mineral abundances of the rock (Xiao et al., 2016; Bai et al., 2017, 2018), chromites in silicate cumulates and silicate minerals in massive and anti-nodular chromitites are expected to have been the most affected.

\section{SAMPLES AND ANALYTICAL METHODS}

Samples analyzed in this study were collected from the Peridotite Zone of the Ultramafic Series. Fourteen samples, including poikilitic harzburgites and different types of chromitites, were collected from the cyclic chromitite units of seams B and G in the Benbow area and Mountain View, and seven samples, including dunite, granular harzburgite, and bronzitite, were collected from the un-mineralized lowermost cyclic unit in the Gish area (Fig. 1b).

\subsection{Chromium elemental analysis}

Selected samples were prepared as $30-\mu \mathrm{m}$-thick polished and carbon coated thin sections. The major element compositions of chromite, orthopyroxene, and olivine, as well as $\mathrm{Cr}_{2} \mathrm{O}_{3}$ profiles in chromite and orthopyroxene, were deter- mined by wavelength-dispersive spectrometry (WDS) using a JEOL JXA8100 electron probe at the State Key Laboratory of Lithospheric Evolution, Institute of Geology and Geophysics, Chinese Academy of Sciences, Beijing, China. Analyses were performed with an accelerating voltage of $15 \mathrm{kV}, 12 \mathrm{nA}$ beam current, $5 \mu \mathrm{m}$ beam spot size, $10-30 \mathrm{~s}$ dwell time, and $11 \mathrm{~mm}$ working distance. A LIFH crystal was used for $\mathrm{Cr}, \mathrm{Mn}, \mathrm{Fe}$, and $\mathrm{Ni}$ analyses, a PETJ crystal for $\mathrm{K}, \mathrm{Ca}$, and $\mathrm{Ti}$, and a TAP crystal for $\mathrm{Na}, \mathrm{Mg}, \mathrm{Al}$, and $\mathrm{Si}$. Standards used were albite for $\mathrm{Na}$, diopside for $\mathrm{Si}, \mathrm{Ca}$, and $\mathrm{Mg}$, hematite and synthetic $\mathrm{Cr}_{2} \mathrm{O}_{3}$ for $\mathrm{Cr}$, synthetic $\mathrm{TiO}_{2}$ for $\mathrm{Ti}$, orthoclase for $\mathrm{K}$, synthetic $\mathrm{Al}_{2} \mathrm{O}_{3}$ for $\mathrm{Al}$, synthetic $\mathrm{MnO}$ for $\mathrm{Mn}$, and synthetic $\mathrm{NiO}$ for $\mathrm{Ni}$. $\mathrm{K}(\alpha)$ lines were selected for analysis, and detection limits were within $\sim 0.008-0.02 \mathrm{wt} \%(1 \sigma)$. Concentration profiles were obtained at $10-15 \mu \mathrm{m}$ increments. Matrix effects were corrected by a program based on the ZAF procedure.

The bulk $\mathrm{Cr}$ concentrations and core-to-rim $\mathrm{Cr}$ concentration profiles of olivines were determined via laser ablation ICP-MS (LA-ICP-MS) using a $193 \mathrm{~nm}$ Coherent COMPex Pro ArF Excimer laser coupled to an Agilent 7500 ICP-MS at the Institute of Geology and Geophysics, Chinese Academy of Sciences, Beijing, China. Prior to analysis, thin sections were treated with $3 \% \mathrm{HNO}_{3}$ followed by de-ionized water and ethylene to remove the carbon coating. We used an approach similar to that of Wu et al. (2018), and isotopes were measured in peak-jumping mode with a repetition rate of $6 \mathrm{~Hz}$. To correct for timedependent data drift, standards were analyzed after every eight sample analyses. We used ${ }^{53} \mathrm{Cr}$ to determine $\mathrm{Cr}$ contents. Spectral interferences for ${ }^{53} \mathrm{Cr}$ are mainly from plasma and atmospheric gases (e.g., $\mathrm{Ar}, \mathrm{O}_{2}, \mathrm{H}_{2}$ ); thus, each analysis was followed by a 20 -s gas-blank measurement and these interferences were effectively corrected by gas-blank subtraction. Because of the relatively low abundance of $\mathrm{Cr}$ in olivine, we used a relative large laser diameter of $80 \mu \mathrm{m}$ to achieve a sufficiently intense ${ }^{53} \mathrm{Cr}$ signal. The laser energy density was $\sim 5 \mathrm{~J} / \mathrm{cm}^{-2}$. Helium was used as the ablation gas to improve the transport efficiency of the ablated aerosols. National Institute of Standards and Technology (NIST) reference materials NIST610 and NIST612 (GeoReM: http://georem.mpch-mainz.gwdg.de/) were used as external standards to produce calibration curves. Calibration was performed using NIST612 as an external standard, and the $\mathrm{Mg}$ contents of olivine served as internal standards. Off-line data processing was performed using GLITTER 4.0 (Griffin, 2008). The accuracies of $\mathrm{Cr}$ and other trace element contents were better than 5\% (1 RSD) with a precision of $10 \%$.

The average $\mathrm{Cr}$ concentrations of orthopyroxene and olivine and the $\mathrm{Cr}_{2} \mathrm{O}_{3}$ contents of chromite in each sample, are reported in Table 1, and the other major element compositions of these minerals and compositional profiles are provided in the Electronic Annex.

\subsection{Chromium isotopic analysis}

Cumulate rocks were crushed to $\sim 250-400 \mu \mathrm{m}$ and fresh mineral grains were handpicked under a binocular microscope. We followed the dissolution procedure described in 
Table 1

Chromium concentration and isotopic compositions of mineral separates in rocks from the Stillwater Complex.

\begin{tabular}{|c|c|c|c|c|c|c|c|c|c|c|c|c|c|}
\hline \multirow[t]{2}{*}{ Location } & \multirow[t]{2}{*}{ Samples } & \multirow[t]{2}{*}{ Lithology } & $\mathrm{Cr}(\mathrm{ppm})$ & Standard deviation & $\delta^{53} \mathrm{Cr}(\%)$ & $2 \sigma$ & $\mathrm{Cr}(\mathrm{ppm})$ & Standard deviation & $\delta^{53} \mathrm{Cr}(\%)$ & $2 \sigma$ & $\mathrm{Cr}_{2} \mathrm{O}_{3}(\mathrm{wt} \%)$ & $\delta^{53} \mathrm{Cr}(\%)$ & $2 \sigma$ \\
\hline & & & \multicolumn{4}{|l|}{ Olivine } & \multicolumn{4}{|c|}{ Orthopyroxene } & \multicolumn{3}{|l|}{ Chromite } \\
\hline Lowermost layer & $16 \mathrm{SW}-3-4$ & Dunite & 23 & 3.70 & 0.14 & 0.05 & 4239 & 413 & 0.00 & 0.05 & 44.87 & -0.20 & 0.05 \\
\hline Lowermost layer & 16SW-3-3 & Dunite & 28 & 4.30 & 0.26 & 0.05 & 3604 & 225 & 0.03 & 0.05 & 45.38 & -0.18 & 0.05 \\
\hline Lowermost layer & $16 \mathrm{SW}-3-2$ & Dunite & 36 & 3.80 & 0.16 & 0.05 & 2844 & 226 & 0.01 & 0.05 & 44.52 & -0.19 & 0.05 \\
\hline Lowermost layer & 16SW-3-9 & Granular harzburgite & 32 & 10.7 & 0.25 & 0.05 & 3272 & 319 & -0.06 & 0.05 & 45.82 & -0.17 & 0.05 \\
\hline Lowermost layer & $16 \mathrm{SW}-3-5$ & Granular harzburgite & 31 & 9.20 & 0.07 & 0.05 & 3084 & 246 & -0.01 & 0.05 & 44.47 & -0.16 & 0.05 \\
\hline Lowermost layer & $16 \mathrm{SW}-3-11$ & Granular harzburgite & 39 & 4.60 & -0.09 & 0.05 & 3267 & 397 & -0.11 & 0.04 & 44.23 & -0.14 & 0.05 \\
\hline Lowermost layer & 16SW-3-6 & Bronzitite & & & & & 3824 & 479 & -0.11 & 0.04 & & & \\
\hline G chromitite & $16 \mathrm{SW}-1-15$ & Poikilitic harzburgite & 34 & 2.70 & 0.04 & 0.05 & 4211 & 212 & 0.07 & 0.07 & 39.62 & -0.18 & 0.05 \\
\hline G chromitite & $16 \mathrm{SW}-1-9$ & Disseminated chromitite & 24 & 3.50 & 0.14 & 0.05 & 2778 & 333 & & & 42.44 & -0.14 & 0.05 \\
\hline G chromitite & $16 \mathrm{SW}-1-27$ & Disseminated chromitite & 18 & 4.90 & 0.03 & 0.05 & 4119 & 247 & & & 43.38 & -0.07 & 0.05 \\
\hline G chromitite & $16 \mathrm{SW}-1-8$ & Anti-nodular chromitite & 29 & 3.90 & 0.13 & 0.05 & 3050 & 518 & & & 45.13 & -0.13 & 0.05 \\
\hline G chromitite & $16 \mathrm{SW}-1-26$ & Anti-nodular chromitite & 27 & 5.10 & 0.07 & 0.05 & 3460 & 384 & & & 44.84 & -0.08 & 0.05 \\
\hline B chromitite & $16 \mathrm{SW}-2-21$ & Disseminated chromitite & & & & & & & & & 36.78 & -0.23 & 0.05 \\
\hline B chromitite & $16 \mathrm{SW}-2-12$ & Disseminated chromitite & & & & & & & & & 45.69 & -0.11 & 0.05 \\
\hline B chromitite & $16 \mathrm{SW}-2-4$ & Disseminated chromitite & & & & & & & & & 40.46 & -0.16 & 0.05 \\
\hline B chromitite & $16 \mathrm{SW}-2-17$ & Disseminated chromitite & & & & & & & & & 43.94 & -0.20 & 0.05 \\
\hline B chromitite & $16 \mathrm{SW}-2-8$ & Disseminated chromitite & & & & & & & & & 46.47 & -0.15 & 0.05 \\
\hline B chromitite & $16 S W-2-14$ & Anti-nodular chromitite & & & & & & & & & 47.11 & -0.14 & 0.05 \\
\hline B chromitite & $16 \mathrm{SW}-2-13$ & Massive chromitite & & & & & & & & & 43.12 & -0.18 & 0.05 \\
\hline B chromitite & $16 \mathrm{SW}-2-15$ & Massive chromitite & & & & & & & & & 47.78 & -0.15 & 0.05 \\
\hline B chromitite & $16 \mathrm{SW}-2-6$ & Massive chromitite & & & & & & & & & 42.42 & -0.15 & 0.05 \\
\hline
\end{tabular}


detail by Qin et al. (2010) and briefly summarized here. Olivine and orthopyroxene separates were dissolved overnight in capped Savillex beakers by a mixture of $\mathrm{HF}, \mathrm{HCl}$, and $\mathrm{HNO}_{3}$ at $130{ }^{\circ} \mathrm{C}$ on a hot plate in a laminar flow exhaust hood. Chromite separates were ground to a very fine powder and dissolved in concentrated 3:1 $\mathrm{HF}-\mathrm{HNO}_{3}$ in a microwave oven at increasing temperatures of 180, 210, 220, and $225^{\circ} \mathrm{C}$ at half hour intervals. After complete digestion, the $\mathrm{Cr}$ concentrations of the sample solutions were analyzed by ICP-MS to ensure that sample aliquots containing $1 \mu \mathrm{g} \mathrm{Cr}$ could be prepared and mixed with a $1 \mathrm{ml}{ }^{50} \mathrm{Cr}-{ }^{54} \mathrm{Cr}$ double spike ${ }^{50} \mathrm{Cr}$ and ${ }^{54} \mathrm{Cr}$ concentrations of 2.716 and $1.742 \mathrm{nmol} / \mathrm{g}$, respectively). The detailed double spike procedure was reported in Han et al. (2012). The sample-spike mixture was dried completely, mixed with $0.2 \mathrm{ml} 6 \mathrm{~N} \mathrm{HCl}$, and heated at $130{ }^{\circ} \mathrm{C}$ for $2-3 \mathrm{~h}$ before chromatographic separation by a two-step cation exchange chromatography procedure (Qin et al., 2010) using Bio-Rad 200-400 mesh AG50-X8 resin in both columns. Procedural blanks were generally less than $3 \mathrm{ng}$, which was negligible in all cases.

Chromium isotopic analyses of mineral separates were performed using a Thermo-Fisher Neptune Plus MC-ICPMS at the CAS Key Laboratory of Crust-mantle Materials and Environments, University of Science and Technology of China, Hefei. The medium- to high-resolution modes were used during analyses of chromium isotopes $(5500<\Delta \mathrm{M} / \mathrm{M}<11,000$, Bonnand et al., 2016) to resolve polyatomic interferences, and the desolvator was operated with only $\mathrm{Ar}$ gas (i.e., without the addition of $\mathrm{N}_{2}$ ) to minimize polyatomic interferences from ${ }^{40} \mathrm{Ar}^{14} \mathrm{~N}^{+}$and ${ }^{40} \mathrm{Ar}^{16} \mathrm{O}^{+}$. During each analytical session, the spiked internal standard (SCP) was analyzed after every four to five sample analyses to ensure instrumental stability. Most samples were analyzed two or more times during a single analytical session. The reported uncertainties for individual sample analyses are conservatively defined as the largest of the 2SD uncertainties of replicate sample measurements, the 2SD uncertainties of replicate standard measurements in the same session, or the long-term reproducibility of the peridotite standard JP-1. Chromium isotopic data are expressed relative to NIST standard reference material (SRM) 979 as $\delta^{53} \mathrm{Cr} \quad[\% o]=\left[\left({ }^{53} \mathrm{Cr} /{ }^{52} \mathrm{Cr}\right)_{\text {sample }} /\left({ }^{53} \mathrm{Cr} /{ }^{52}\right.\right.$ $\left.\mathrm{Cr})_{\text {SRM }} 979-1\right] \times 1000$. The spiked NIST SRM 3112a was analyzed at the beginning of each session; we obtained an average $\delta^{53} \mathrm{Cr}$ value of $-0.09 \pm 0.03 \%$ o $(n=9,2 \mathrm{SD})$, consistent with the value of $-0.07 \pm 0.05 \%$ o reported by Schoenberg et al. (2008). The average $\mathrm{Cr}$ isotopic composition of peridotite standard JP-1 $(-0.11 \pm 0.03 \%$, $n=9)$ was also in agreement with published values $(-0.13$ $\pm 0.02 \%$; Bonnand et al., 2016).

\section{RESULTS}

\subsection{Elemental $\mathrm{Cr}$ concentrations}

Average olivine $\mathrm{Cr}$ concentrations per sample range from 18 to $39 \mathrm{ppm}$ (Table 1), and olivine grains from silicate cumulates commonly have lower $\mathrm{Cr}$ contents than those from chromitites (Fig. 3). Average orthopyroxene $\mathrm{Cr}$ concentrations per sample are higher than those of oli-

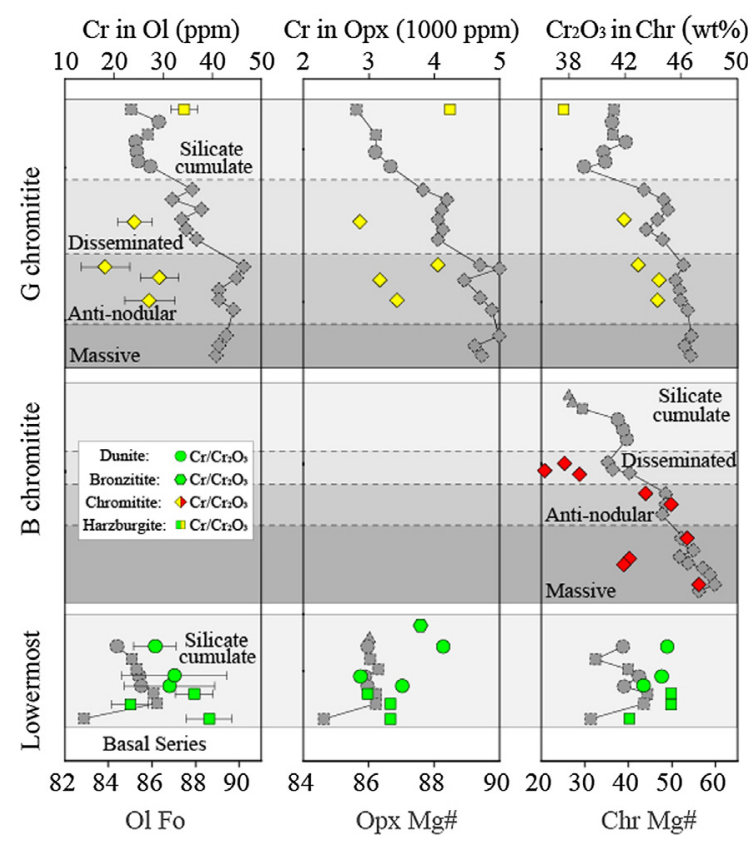

Fig. 3. Variations of $\mathrm{Cr}$ content in olivine and orthopyroxene, and $\mathrm{Cr}_{2} \mathrm{O}_{3}$ content in chromite. Gray symbols with dashed lines represent the corresponding Fo composition of olivine and $\mathrm{Mg \#}$ $\left[100 \times \mathrm{Mg}^{2+} /\left(\mathrm{Mg}^{2+}+\mathrm{Fe}^{2+}\right)\right]$ of orthopyroxene and chromite (see Table S1).

vine, ranging from 2778 to $4239 \mathrm{ppm}$ (Table 1), and are not distinguishable based on lithology (Fig. 3). Systematic $\mathrm{Cr}$ content variations were observed in profiles traversing silicate minerals. Olivine $\mathrm{Cr}$ contents are highest in their cores $(\sim 60 \mathrm{ppm})$ and decrease to $\sim 20 \mathrm{ppm}$ near their rims (Fig. $4 \mathrm{a}, \mathrm{b})$. The $\mathrm{Cr}$ concentrations of orthopyroxene grains similarly decrease by up to a factor of two from their cores (4970 and $4620 \mathrm{ppm}$ in samples 16SW-3-3 and 16SW-3-5, respectively) toward their grain boundaries (2690 and 2440 ppm, respectively; Fig. 4b). Average chromite $\mathrm{Cr}_{2} \mathrm{O}_{3}$ contents per sample vary markedly from 36.8 to $47.8 \mathrm{wt} \%$ (Table 1), with the highest values observed in massive chromitites and the lowest in silicate cumulates (Fig. 3), consistent with previous studies (e.g., Campbell and Murck, 1993). Chromite $\mathrm{Cr}_{2} \mathrm{O}_{3}$ concentration profiles are homogenous in each sample, with variations commonly less than $1 \mathrm{wt} \%$ (Table $\mathrm{S} 2$ ).

\section{2. $\mathrm{Cr}$ isotopes}

The $\delta^{53} \mathrm{Cr}$ values of chromites in the different rock suites and layers are extremely restricted, ranging from -0.07 to $-0.23 \%$ (Table 1), similar to spinel from other maficultramafic rock suites and mantle xenoliths (Fig. 5; Farkaš et al., 2013; Xia et al., 2017; Shen et al., 2018; Chen et al., 2019). This is in agreement with the restricted $\delta^{53} \mathrm{Cr}$ values $(-0.12 \pm 0.10 \%$ ) reported for igneous rocks from various tectonic settings and with varying chemical parameters (Schoenberg et al., 2008). In addition, chromite $\delta^{53} \mathrm{Cr}$ values are roughly consistent with the whole-rock values, as observed for ophiolites (Farkaš et al., 2013; Shen 

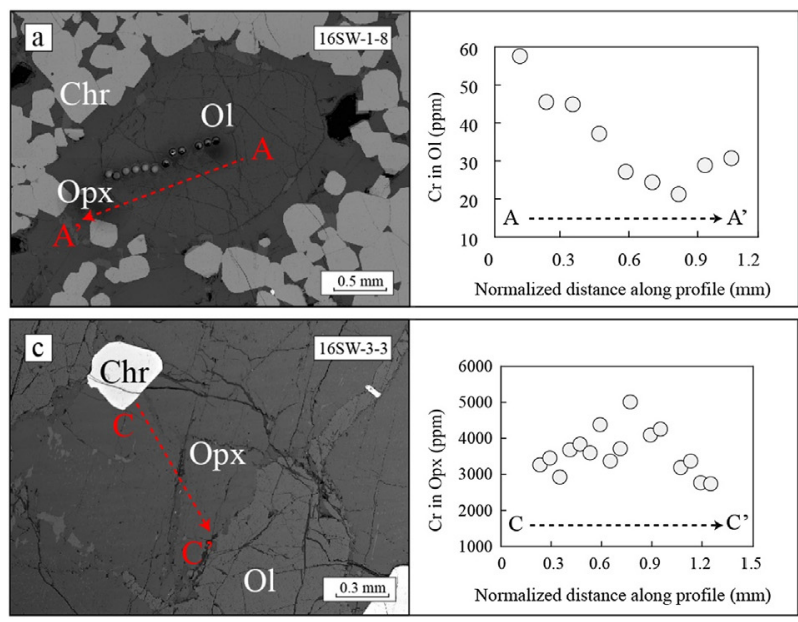
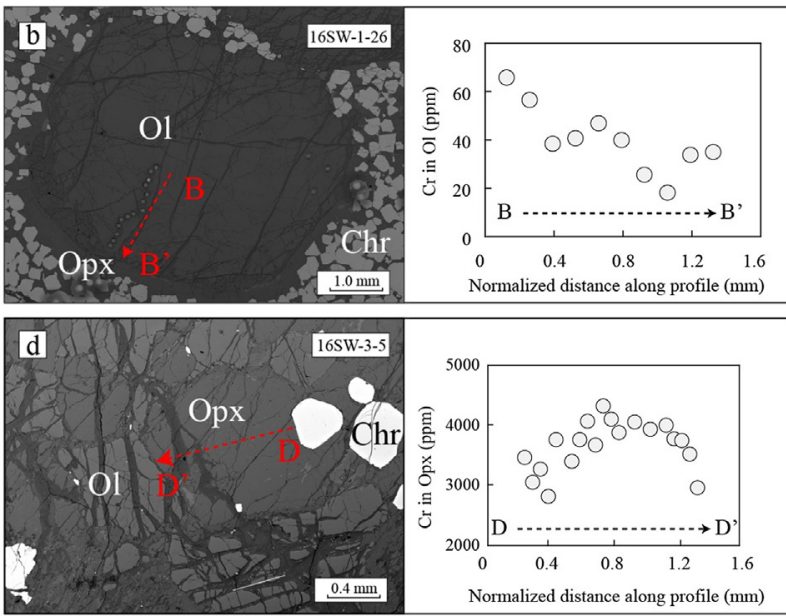

Fig. 4. Core-to-rim chromium concentration profiles in olivine extended to traverse adjacent orthopyroxene in (a) sample 16SW-1-8 (antinodular chromitite), (b) sample 16SW-1-26 (anti-nodular chromitite), (c) sample 16SW-3-3 (dunite), and (d) sample 16SW-3-3 (granular harzburgite).

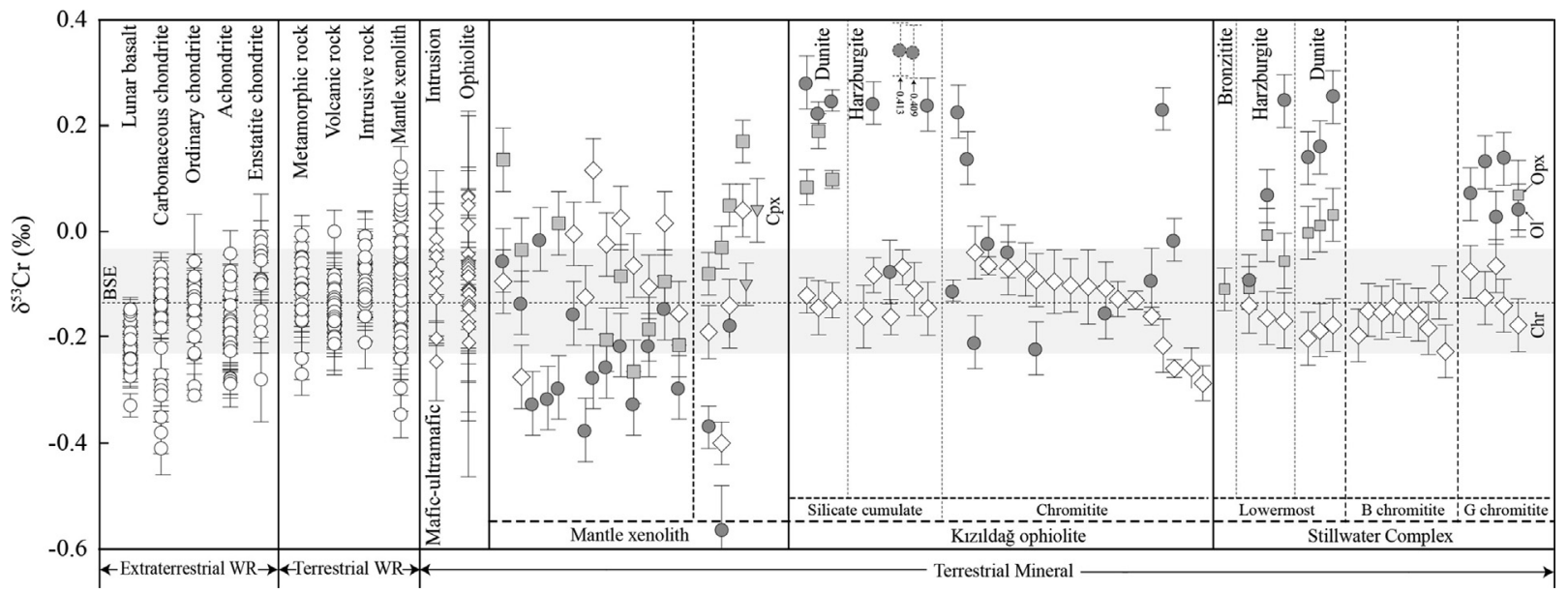

Fig. 5. Chromium isotopic compositions of olivine, orthopyroxene, and chromite in the Stillwater Complex (far right panel) compared to published terrestrial mineral and whole-rock data (central panels) and extraterrestrial whole-rock data (far left panel). Circles represent olivine, squares represent orthopyroxene, and diamonds represent chromite. Silicate mineral $\delta^{53} \mathrm{Cr}$ values are from Xia et al. (2017), Shen et al. (2018), Chen et al. (2019) and, and $\delta^{53} \mathrm{Cr}$ values of chromite in other mafic-ultramafic intrusions and ophiolites are from, Chen et al. (2019), Farkaš et al. (2013) and Shen et al. (2015). Terrestrial and extraterrestrial whole-rock $\delta^{53} \mathrm{Cr}$ values are from Moynier et al. (2011), Farkaš et al. (2013), Bonnand et al. (2016), and Schoenberg et al. (2008, 2016). The range of BSE values is from Schoenberg et al. (2008). Reported errors are 2SE.

et al., 2015), mantle xenoliths (Xia et al., 2017), other types of ultramafic/mafic intrusions (Farkaš et al., 2013), and meteorites (e.g., Moynier et al., 2011; Schiller et al., 2014, Schoenberg et al., 2016).

In contrast to chromite, olivine and orthopyroxene $\delta^{53} \mathrm{Cr}$ values show variations from -0.09 to $0.25 \%$ and -0.11 to $0.07 \%$, respectively (Fig. 5). Olivine grains have higher and more variable $\delta^{53} \mathrm{Cr}$ values than orthopyroxene, and almost all silicate minerals in the Stillwater Complex have higher $\delta^{53} \mathrm{Cr}$ values than chromite. These characteristics are opposite the inter-mineral equilibrium fractiona- tions observed in mantle xenoliths, for which $\delta^{53} \mathrm{Cr}_{\mathrm{Spl}}>\delta^{53} \mathrm{Cr}_{\mathrm{Opx}}>\delta^{53} \mathrm{Cr}_{\mathrm{Ol}}$ (Xia et al., 2017; Shen et al., 2018).

\section{DISCUSSION}

Chromium isotopic variations in olivine, orthopyroxene, and chromite may result from either equilibrium fractionation or diffusion-driven kinetic fractionation. In this section, we first discuss the mechanism governing the observed $\mathrm{Cr}$ isotopic variations in these minerals during 
magmatic processes. Then, we explore potential petrologic applications.

\subsection{Equilibrium chromium isotopic fractionation}

The restricted range of chromite $\delta^{53} \mathrm{Cr}$ values in our results $(-0.23$ to $-0.07 \%$ overlaps the narrow range reported for the $\mathrm{BSE}\left(\delta^{53} \mathrm{Cr}=-0.22\right.$ to $-0.02 \%$; Schoenberg et al., 2008). However, we note chromite $\mathrm{Cr}$ isotopic variations in our data, specifically those from the $\mathrm{B}$ and $\mathrm{G}$ chromite seams (Fig. 6a, b). Chemical exchanges play an important role in modifying isotopic compositions (e.g., for Fe and Mg isotopes; see Teng et al., 2011; Chen et al., 2018), but the $\delta^{53} \mathrm{Cr}$ values of chromite grains are expected to be insensitive to chemical exchanges due to the huge $\mathrm{Cr}$ concentrations in chromite relative to other phases (e.g., Drake et al., 1989; Ohtani et al., 1989). Chromites are thus expected to maintain their original $\mathrm{Cr}$ isotopic compositions during cooling.

Some $\mathrm{Cr}$ isotopic variations in chromite may be induced by magmatic differentiation, as observed in ophiolitic samples (Chen et al., 2019) and terrestrial and lunar basalts (Bonnand et al., 2016; Xia et al., 2017). During differentiation, heavy $\mathrm{Cr}$ isotopes are preferentially partitioned into chromite and light ones into the residual melt (Farkaš et al., 2013; Shen et al., 2015, 2018; Xia et al., 2017). The range of $\mathrm{Cr}$ isotopic compositions observed in chromites of this study (Fig. 6a, b) could have been induced by abundant chromite crystallization in the $B$ and $G$ chromite seams. Indeed, massive chromitite crystallization at the base of every cyclic chromitite unit (Raedeke and McCallum, 1984; McCallum, 1996) could have enriched the residual melt in light $\mathrm{Cr}$ isotopes. Chromite grains that subsequently crystallized from the residual melt (i.e., in anti-nodular and disseminated chromitites and silicate cumulates) would naturally have lighter $\mathrm{Cr}$ isotopic compositions. The $\delta^{53} \mathrm{Cr}$ values of chromite, especially in the $\mathrm{B}$ and $\mathrm{G}$ chromite seams, correlate negatively with indices of magmatic differentiation, such as chromite $\mathrm{Mg \#}$ (Fig. 6a) and $\mathrm{TiO}_{2}$ content (Fig. 6b) (e.g., Barnes and Roeder, 2001; Bai et al., 2017). This provides further evidence that the observed $\mathrm{Cr}$ isotopic variations could have been induced by chromite fractionation during magmatic differentiation.

The massive chromitites formed at the base of each cyclic sequence have the closest $\mathrm{Cr}$ isotopic compositions to the BSE value (Fig. 6c). Interestingly, a few anti-nodular and disseminated chromitites are isotopically heavier than the massive chromitites (Fig. 6c), although, as discussed above, they should be isotopically lighter with $\delta^{53} \mathrm{Cr}$ values between those of the massive chromitites and the residual melt. This is hard to reconcile in a closed magmatic system, and contamination by isotopically heavy Si-rich sedimentary rocks might have produced the elevated $\delta^{53} \mathrm{Cr}$ values in those chromitites (e.g., Qin and Wang, 2017). The residual melt from which the anti-nodular and disseminated chromitites formed had a lower $\mathrm{Cr}$ content than the primitive melt that produced the massive chromitites. Therefore, the $\mathrm{Cr}$ isotopic composition of the $\mathrm{Cr}$-poor residual melt would have been more easily influenced by such sedimentary rocks, such that anti-nodular and disseminated chromitites that formed later would be isotopically heavier than massive chromitites that had formed earlier in the sequence. The $\mathrm{Cr}$ isotopic compositions of chromites thus show that the injected primitive melt and assimilation of the surrounding rocks are two factors responsible for the formation of the isotopically distinct chromitites in the Stillwater Complex. This conclusion is supported by the presence of crust-derived inclusions in those lithologies (Spandler et al., 2005) and results from chemical modeling of the parent magma of the Peridotite Zone (Jenkins and Mungall, 2018).

\subsection{Diffusion-driven kinetic chromium isotopic fractionation}

Theoretical predictions (Moynier et al., 2011; Farkaš et al., 2013; Shen et al., 2015, 2018) and data from mantle xenoliths (Fig. 5; Xia et al., 2017) show that mineralspecific $\mathrm{Cr}$ isotopic compositions attained by equilibrium inter-mineral $\mathrm{Cr}$ isotopic fractionation should follow the general order $\delta^{53} \mathrm{Cr}_{\mathrm{Spl}}>\delta^{53} \mathrm{Cr}_{\mathrm{Opx}}>\delta^{53} \mathrm{Cr}_{\mathrm{Ol}}$. Inter-mineral fractionation factors are also controlled by temperature and oxygen fugacity (Shen et al., 2018), which affect the charge and coordination environment of $\mathrm{Cr}$ (e.g.,
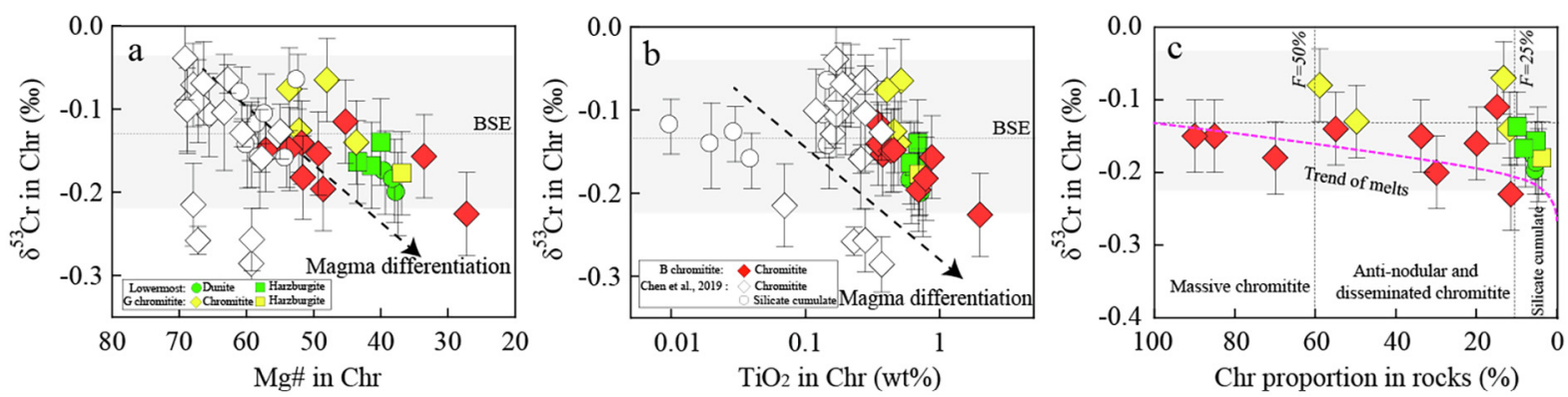

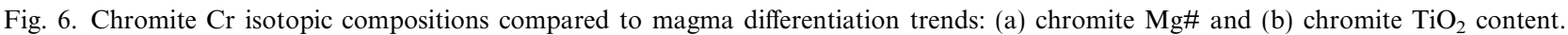
Dashed lines represent the trend of magma differentiation. (c) The calculated trend of the $\mathrm{Cr}$ isotopic evolution of the melt during fractional crystallization of chromite. The horizontal axis represents the chromite proportion in different samples, which are calculated by mass balance (Table S4). $F$ is the fraction of $\mathrm{Cr}$ in the residual melt relative to that in the primary melt. The isotopic evolution of the melt is calculated from Shen et al. (2018). The range of BSE values is from Schoenberg et al. (2008). 
Polyakov and Mineev, 2000; Polyakov et al., 2007). However, we observed the reverse order of $\delta^{53} \mathrm{Cr}_{\mathrm{Ol}} \geq \delta^{53}$ $\mathrm{Cr}_{\mathrm{Opx}}>\delta^{53} \mathrm{Cr}_{\mathrm{Chr}}$ (Fig. 5), and mineral pairs plot far from the equilibrium inter-mineral isotopic fractionation lines defined for mantle xenoliths by Xia et al. (2017) and Shen et al. (2018) (Fig. 7), indicating disequilibrium fractionation in our samples.

Significant disequilibrium isotopic fractionations have been observed during magmatic processes in a variety of environments for elements including $\mathrm{Li}, \mathrm{Fe}$, and $\mathrm{Mg}$ (e.g., Teng et al., 2011; Oeser et al., 2015; Collinet et al., 2017). Light isotopes diffuse faster than heavy ones during elemental diffusion (Richter et al., 2009), therefore subsolidus $\mathrm{Cr}$ diffusion should also result in disequilibrium isotopic fractionation via Soret (e.g., Richter et al., 2009; Huang et al., 2010) or chemical diffusion (e.g., Richter et al., 2009; Teng et al., 2011). Soret diffusion could produce large $\mathrm{Cr}$ isotopic fractionations, with heavy $\mathrm{Cr}$ isotopes preferentially diffusing down the thermal gradient. However, Soret diffusion cannot be responsible for the heavy $\mathrm{Cr}$ isotopic compositions observed here in silicate minerals because thermal diffusivity (Lesher and Walker, 1986) is dozens of orders of magnitude faster than that of elemental $\mathrm{Cr}$ in minerals (Ganguly et al., 2007; Posner et al., 2016; Jollands et al., 2017). It is thus reasonable to assume that no measurable or long-lasting temperature gradient can occur at the grain scale. Hence, it is more likely that the kinetic mechanisms of $\mathrm{Cr}$ diffusion derive from chemical diffusion.

Chemical diffusion during crystal growth is often induced by the concentration gradients caused by the changing composition of the equilibrium melt, as typically inferred from elemental zonings in mineral (Pre $\beta$ et al., 1986; Bai et al., 2018; Guotana et al., 2018). Isotopic evidence of $\mathrm{Cr}$ chemical diffusion has also been reported during mantle processes in which $\mathrm{Cr}$ diffuses from high-Cr melt to adjacent peridotites (Xia et al., 2017), imprinting light $\mathrm{Cr}$ isotopic signatures into the rock-forming minerals (Fig. 7). This is most obviously observed in olivine grains with $\delta^{53} \mathrm{Cr}$ values (and $\mathrm{Cr}$ concentrations) lower than those of spinel (Fig. 7a) and orthopyroxene (Fig. 7b). However, Cr diffusion from melt to silicate minerals could cause lighter $\mathrm{Cr}$ isotopic compositions in the silicate minerals (Fig. 5) and decreasing $\mathrm{Cr}$ contents from their cores to rims (Fig. 4). Alternatively, chemical diffusion can occur due to the elemental disequilibrium induced by variable physicochemical states. The compatibility of $\mathrm{Cr}$ in olivine and orthopyroxene are commonly inconstant (e.g., DOpx/melt $\mathrm{Cr}=0.55-2.2, \mathrm{DOl} / \mathrm{melt} \mathrm{Cr}=0.45-1.3$; Kennedy et al., 1993). Specifically, the solubility of $\mathrm{Cr}$ in silicate minerals decreases with decreasing temperature (Papike et al., 2005; Jollands et al., 2017), and Cr should diffuse from silicate minerals to the melt during cooling. Grain-boundary diffusion is also an order of magnitude faster than volume diffusion, and both occur in minerals (Freer, 1981; Ganguly, 2002). Accordingly, silicate minerals in our samples show decreasing core-to-rim $\mathrm{Cr}$ profiles (Fig. 3) and have heavy $\mathrm{Cr}$ isotopic compositions that plot away from the equilibrium fractionation line (Fig. 7).

Inter-mineral $\mathrm{Cr}$ isotopic fractionation factors $\left(\Delta^{53} \mathrm{Cr}_{\mathrm{A}-\mathrm{B}}=\delta^{53} \mathrm{Cr}_{\mathrm{A}}-\delta^{53} \mathrm{Cr}_{\mathrm{B}}\right.$, where $\mathrm{A}$ and $\mathrm{B}$ are two mineral phases) were estimated by Shen et al. (2018). Overall, our samples show disequilibrium isotopic fractionations (Fig. 8). Chromite-olivine pairs in silicate cumulates tend to have larger fractionation factors than those in chromitites (Fig. 8a). This may be attributed to migration of the interstitial melt. Chromitites generally form by the rapid sorting (sinking) and accumulation of chromite, and efficient compaction of the earliest accumulated chromitites will cause the upward migration of any interstitial melt (Raedeke and McCallum, 1984; Boudreau, 2016). Consequently, silicate minerals in chromitites are likely less affected by $\mathrm{Cr}$ diffusion in the interstitial melt (Manoochehri and Schmidt, 2014; Jenkins and Mungall, 2018). On the other hand, if the interstitial melt maintains elemental exchange with the parental magma of the silicate cumulates overlying the chromitites, the prolonged exchange between the two melts would generate larger fractionations between minerals of the two lithologies. The sole exception in our data is sample $16 \mathrm{SW}-3-11$, which is located close to the chilled margin of the Basal Series and thus cooled rapidly without undergoing protracted diffusion. This sample thus preserves relatively primary $\mathrm{Cr}$ isotopic
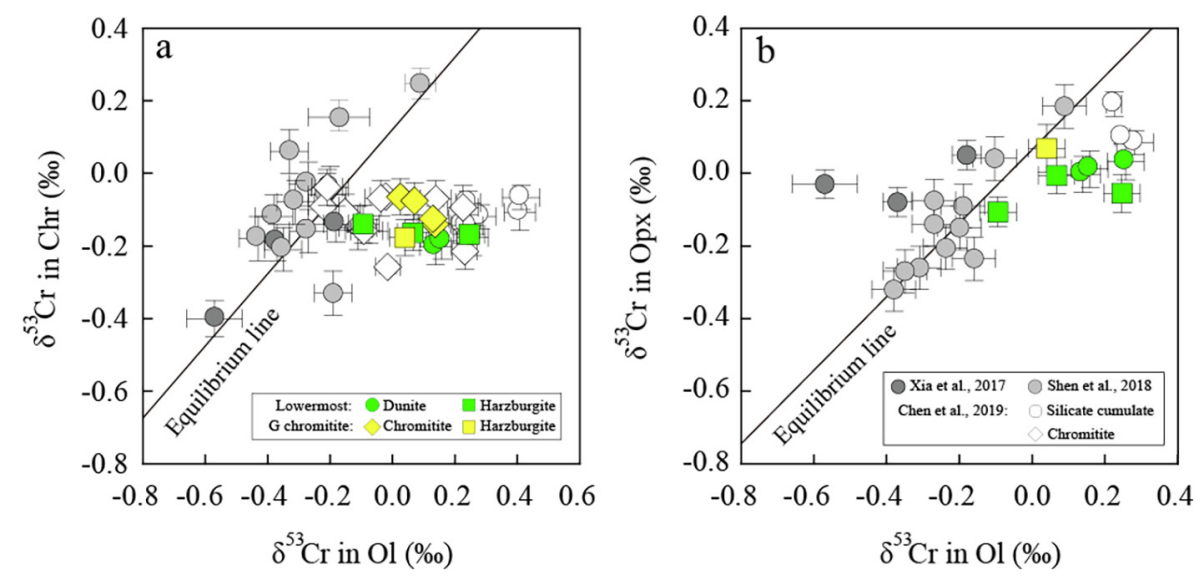

Fig. 7. Inter-mineral $\mathrm{Cr}$ isotopic fractionations between (a) olivine and chromite and (b) olivine and orthopyroxene. Solid lines represent the equilibrium fractionation lines defined from mineral pairs in mantle xenoliths (Xia et al., 2017; Shen et al., 2018). 

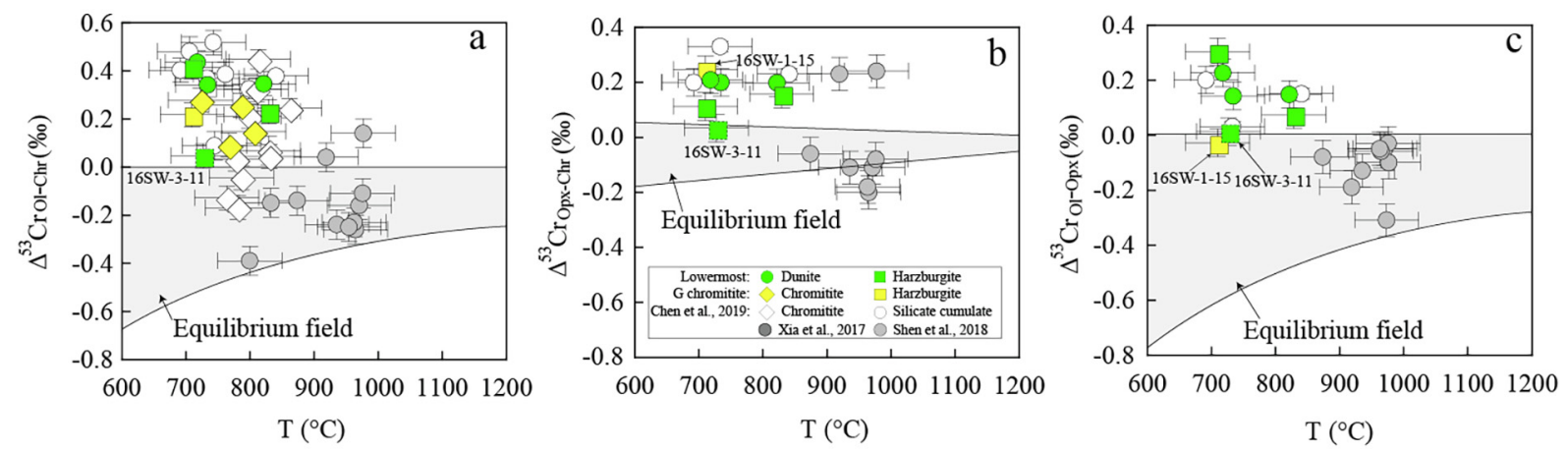

Fig. 8. Calculated (a) olivine-chromite, (b) orthopyroxene-chromite, and (c) olivine-orthopyroxene inter-mineral equilibrium Cr isotopic fractionation factors as a function of temperature in the Stillwater Complex, compared with samples from Shen et al. (2018) and Chen et al. (2019). The gray field denotes isotopic fractionations arising from equilibrium processes (Shen et al., 2018).

compositions and displays the lowest isotopic fractionation factor (Fig. 8).

The characteristic $\delta^{53} \mathrm{Cr}_{\mathrm{Ol}}>\delta^{53} \mathrm{Cr}_{\mathrm{Opx}}$ values between olivine and granular orthopyroxene may be due to the low $\mathrm{Cr}$ contents of olivine, which could have been significantly affected by extrinsic heavy $\mathrm{Cr}$ isotopes. Orthopyroxenes in the poikilitic harzburgite sample 16SW-1-15 have $\mathrm{Cr}$ isotopic compositions similar to those of olivine from the same sample. This is expected because the poikilitic orthopyroxene formed from the reaction between olivine and trapped melt (Jackson, 1961; Barnes, 1986). Poikilitic orthopyroxenes thereby inherited the $\mathrm{Cr}$ isotopic compositions of their precedent olivines, i.e., heavier $\delta^{53} \mathrm{Cr}$ values than granular orthopyroxenes.

\subsection{Constraints on the cooling time of the Stillwater Complex}

$\mathrm{Li}, \mathrm{Fe}$, and $\mathrm{Mg}$ elemental and isotopic zonings induced by inter-mineral disequilibrium are widely observed in intrusive rocks (e.g., Chen et al., 2014; Xiao et al., 2016), volcanic rocks (e.g., Teng et al., 2011), and meteorites (e.g., Collinet et al., 2017), but only constrain cooling histories over short time scales, such as for volcanic rocks and meteorites (Teng et al., 2011; Collinet et al., 2017). For magmatic processes with longer cooling periods, for instance in intrusive rocks, few of the aforementioned elements are zoned, although their isotopic compositions can show evidence of inter-mineral diffusion (Xiao et al., 2016). Zoning patterns of low-valence elements are generally homogenized by rapid diffusion during prolonged subsolidus processes (Yang and Seccombe, 1993). In contrast, some high-valence elements, such as $\mathrm{Ti}$ and $\mathrm{Si}$, are not reequilibrated due to their extremely low diffusivities (Suzuki et al., 2008).

Chromium diffuses slower than $\mathrm{Fe}, \mathrm{Mg}$, and $\mathrm{Li}$, but faster than $\mathrm{Ti}$ and $\mathrm{Si}$ in silicate minerals (e.g., Ito and Ganguly, 2006; Ganguly et al., 2007; Posner et al., 2016), and magmatic minerals thus commonly present $\mathrm{Cr}$ zoning patterns. Indeed, $\mathrm{Cr}$ diffusion profiles in olivine, orthopyroxene, and spinel have been used to calculate the cooling rates of meteorites (e.g., Lugmair and Shukolyukov, 1998; Ito and Ganguly, 2006). Here, we similarly use $\mathrm{Cr}$ diffusion profiles to constrain the cooling history of the Peridotite Zone in the Stillwater magma body.

We developed a simple diffusion model for olivine and orthopyroxene using Mathematica. We use the onedimensional diffusion equation of Richter et al. (1999, 2003), which is a function of the $\mathrm{Cr}$ concentration $(C)$ in olivine or orthopyroxene, the position $(r)$ along the profile, and time $(t)$ :

$\frac{\partial C(r, t)}{\partial t}=\frac{\partial D}{\partial r} \cdot \frac{\partial C(r, t)}{\partial r}+D \frac{\partial^{2} C(r, t)}{\partial r^{2}}$

Elemental $\mathrm{Cr}$ diffusion coefficients $(D)$ in olivine and orthopyroxene are well known to follow an Arrhenius behavior, and become exponentially smaller with decreasing temperature (Ito and Ganguly, 2006; Ganguly et al., 2007), expressed as:

$D=D_{0} \exp (-E / R T)$

where $D_{0}$ is the diffusion constant, $E$ the activation energy, $R$ the gas constant, and $T$ the temperature $(\mathrm{K})$. In addition, $\mathrm{Cr}$ diffusion in olivine and orthopyroxene is anisotropic. Here we assume that $\mathrm{Cr}$ diffusion parallel to different crystallographic axes has different activation energies, and that $D_{0}$ is also strongly dependent on the crystallographic axis. Accordingly, we selected average data for $E$ and $D_{0}$ parallel to the a- and c-axes to represent their activation energies and diffusion constants in olivine (Ito and Ganguly, 2006) and orthopyroxene (Ganguly et al., 2007).

The closure temperature $\left(T_{\mathrm{c}}\right)$ is defined as the temperature at which diffusion effectively ceases during cooling (Dodson, 1973). Ito and Ganguly (2006) and Ganguly et al. (2007) demonstrated that $T_{\mathrm{c}}$ for $\mathrm{Cr}$ in olivine and orthopyroxene is a function of the initial temperature $\left(T_{0}\right)$, grain size, and cooling rate according to the formulation of Ganguly and Tirone (1999):

$\frac{E}{R T_{c}}=\ln \left(-\frac{A^{\prime} R T_{c}^{2} D_{0}}{E(d T / d t)_{@ T_{c}} a^{2}}\right)$

where $(d T / d t)_{T \mathrm{c}}$ is the cooling rate at $T_{\mathrm{c}}$ and $a$ is the radius of olivine grains, set to 500,1000 , and $2000 \mu \mathrm{m}$ for our samples. The function $A^{\prime}$ can be expressed as $A^{\prime}=A \exp (g)$, where $A$ is a geometric factor given by $A=e^{G}$ (Dodson, 
1973), and $G=4.0066$ for spheres, 3.29506 for cylinders, and 2.15821 for plane sheets. The term $g$, which is referred to as a "memory function", is a function of a dimensionless parameter, $M$, given by Dodson (1973) as:

$M=\frac{R D\left(T_{0}\right)}{E \eta a^{2}}$

where $\eta$ is a cooling time constant with units $\mathrm{K}^{-1} \mathrm{t}^{-1}$. The values of $g$ for specific values of $M$ are tabulated in Ganguly and Tirone $(1999,2001)$. In the above equation, $D\left(T_{0}\right)$ is the diffusion coefficient at the peak (initial) temperature, which makes $T_{\mathrm{c}}$ dependent on $T_{0}$. We assume that cooling was asymptotic, described by:

$\frac{1}{T}=\frac{1}{T_{0}}+\eta t$

The thermal models developed by Hess (1972) for the Stillwater Complex assumed a $T_{0}$ value around $1200^{\circ} \mathrm{C}$. Melting experiments performed on samples from the Stillwater Complex showed that olivine was the first phase in the crystallization sequence, with a liquidus temperature of $1200{ }^{\circ} \mathrm{C}$ (Helz, 1995). This temperature is further supported by the presence of $\mathrm{RuS}_{2}$ in the Peridotite Zone, which is stable at or below approximately $1200{ }^{\circ} \mathrm{C}$ (Talkington and Lipin, 1986). Thus, we set $T_{0}$ in our model to $1200{ }^{\circ} \mathrm{C}$. This assumes that the Stillwater magma was injected as a single sill at $1200{ }^{\circ} \mathrm{C}$ into basement rocks at $300{ }^{\circ} \mathrm{C}$, and that the magma cooled below its solidus (e.g., Selkin et al., 2000). Most mineral grains are assumed to have crystallized from the melt and settled into cumulate piles at this initial cooling temperature. We use the cooling rate at any temperature, $T$, instead of that at $T_{\mathrm{c}}$ to obtain curves for $T_{\mathrm{c}}$ vs. cooling rate for specific values of $T_{0}$ and $a$ (Fig. 9).

We calculate the diffusion coefficients of ${ }^{52} \mathrm{Cr}$ and ${ }^{53} \mathrm{Cr}$ using a modified version of Graham's low for molten oxides and crystals (Richter et al., 1999):

$\frac{D_{1}}{D_{2}}=\left(\frac{M_{2}}{M_{1}}\right)^{\beta}$ where $D_{1}$ and $D_{2}$ are the diffusivities and $M_{1}$ and $M_{2}$ the masses of the two analyzed $\mathrm{Cr}$ isotopes. $\beta$ is the isotopic fractionation factor, which remains to be determined for $\mathrm{Cr}$ diffusion in olivine and orthopyroxene; we set it to $\sim 0.16$, similar to the latest empirical results for $\mathrm{Fe}$ isotopes (Sio et al., 2018). This value can be used to describe diffusion along all major crystallographic axes.

The initial $\mathrm{Cr}$ concentration $C_{0}$ is variable in our samples, and we varied its value from 60 to $20 \mathrm{ppm}$ in olivine and from 6000 to $3000 \mathrm{ppm}$ in orthopyroxene. The calculated closure temperatures $\left(T_{\mathrm{c}}=790{ }^{\circ} \mathrm{C}\right.$ for olivine and $760{ }^{\circ} \mathrm{C}$ for orthopyroxene) for grains of radius $a=1000 \mu \mathrm{m}$ were adopted in the diffusion model. Thus, we obtain the $\mathrm{Cr}$ concentrations and isotopic compositions at any position along the grain radius and at different cooling times using the temperature-dependent $\mathrm{Cr}$ diffusion constants; the average concentrations and isotopic compositions are obtained by integration over the grain radius. We explored various cooling times, which yielded different average $\mathrm{Cr}$ concentrations and isotopic compositions, and the various initial $\mathrm{Cr}$ concentrations in the minerals produced different trend lines depending on the cooling time (Fig. 10). We plotted all our analytical data to compare with these model results, and we find that most of our samples are confined to within the trend lines of 10 to $100 \mathrm{kyr}$ cooling times.

\subsection{Petrogenetic applications}

Hess (1972) conducted the earliest study on the cooling history of the Stillwater Complex. They calculated the rate of heat loss from the magma using likely values of thermal diffusion and depth of burial, and estimated the cooling rate of the $2 \mathrm{~km}$-thick rock unit to be about $1{ }^{\circ} \mathrm{C} / \mathrm{kyr}$. The cooling history of the Stillwater Complex was then commonly calculated based on Fe-Mg elemental exchange. Cooling rates of $1-50{ }^{\circ} \mathrm{C} / \mathrm{Myr}$ were obtained using intercrystalline $\mathrm{Fe}-\mathrm{Mg}$ exchange between pyroxenes (Domeneghetti et al., 2001; McCallum et al., 2006). However, this value has a large uncertainty and is much slower than the computed
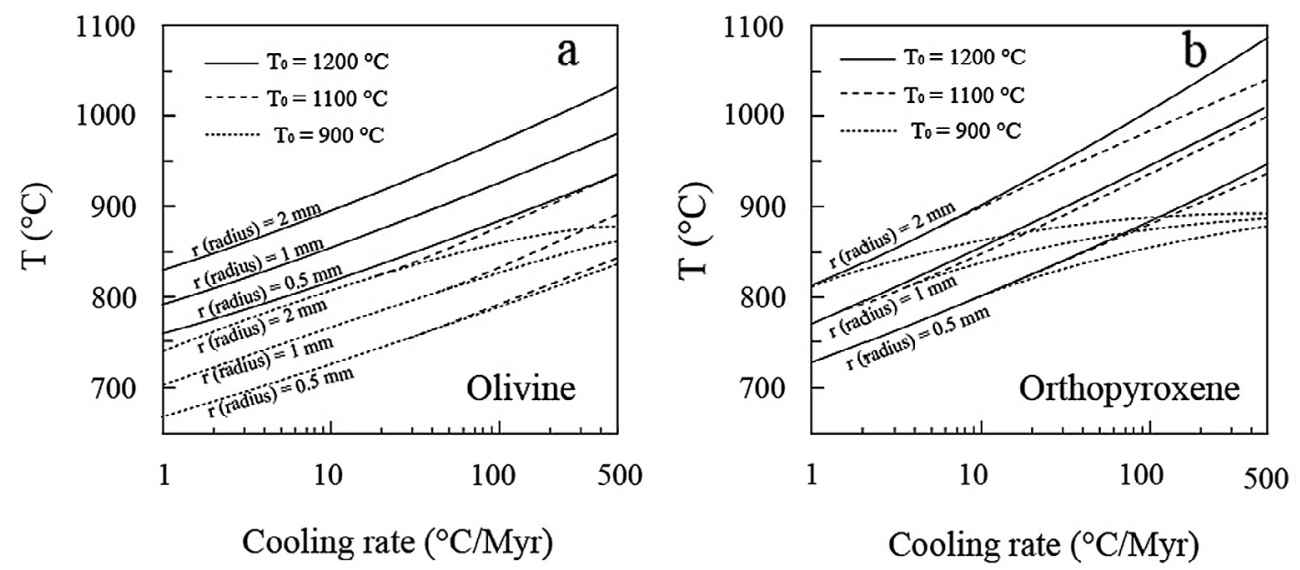

Fig. 9. Closure temperature $\left(T_{\mathrm{c}}\right)$ of $\mathrm{Cr}$ diffusion in olivine and orthopyroxene as a function of the initial temperature ( $\left.T_{0}\right)$, cooling rate, and grain size. The cooling trends for $T_{0}=1100$ and $900{ }^{\circ} \mathrm{C}$ in olivine and orthopyroxene are from Ito and Ganguly (2006) and Ganguly et al. (2007). 

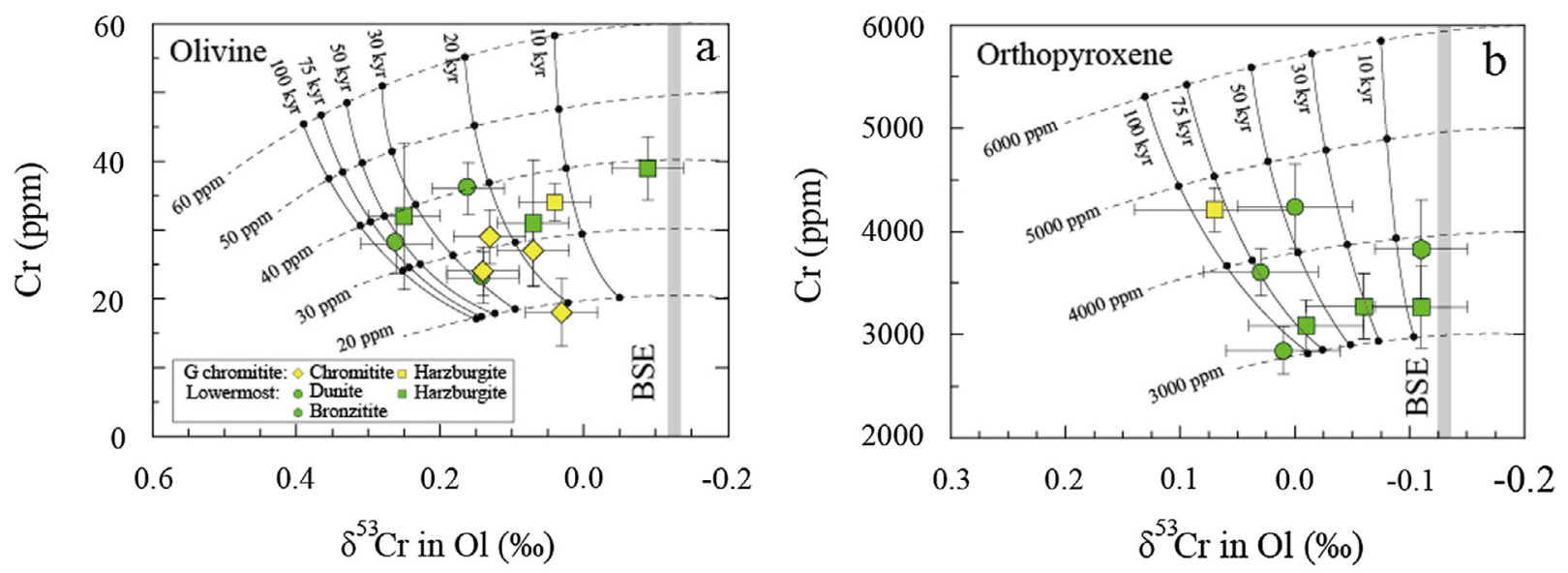

Fig. 10. Modeled Cr contents and isotopic compositions in olivine and orthopyroxene as a function of cooling time. The Cr concentration and isotopic profiles were obtained using the Mathematica diffusion model developed in the text, and average $\mathrm{Cr}$ concentrations and isotopic compositions are calculated by integration over the grain radius. Dashed horizontal lines represent the calculated evolution of Cr contents and isotopic compositions, and the solid lines represent cooling times for different initial Cr concentrations. Model results are compared to the observed $\mathrm{Cr}$ concentrations and isotopic compositions of olivine and orthopyroxene, which restrict the cooling times to $10-100 \mathrm{kyr}$. The BSE value is from Schoenberg et al. (2008).

cooling rate for a terrestrial intrusion (Irvine, 1970; McCallum et al., 2006). The Stillwater Complex was exposed to a low-grade (greenschist facies) metamorphic event at $1.7 \mathrm{Ga}$. Heating associated with this metamorphic event may have induced intracrystalline redistribution of $\mathrm{Fe}$ and $\mathrm{Mg}$, and it is likely that such slow cooling rates reflect this late low-temperature heating event. Micron-scale oscillatory zonings in plagioclase were also used to determine the cooling rate of the Stillwater Complex based on CaAl-NaSi diffusion in plagioclase feldspar (Grove et al., 1984), and their results showed that cooling from 1200 to $1000{ }^{\circ} \mathrm{C}$ required around $100 \mathrm{kyr}$. Recently, Selkin et al. (2006) used a 1-D finite difference conductive cooling model based on an analytic half-space model to estimate the cooling history of the Stillwater Complex. Their results for sites at the top of the Stillwater Complex, where the heat should have been conductively consumed by the surrounding rocks (Coogan et al., 2002), suggest that it may take as little as $20 \mathrm{kyr}$ to cool from 1200 to $580{ }^{\circ} \mathrm{C}$. However, for sites at the bottom of the complex (e.g., the Peridotite Zone) where diffusive cooling dominates, their results suggest that the minimum closure temperature would have been reached about 1 Myr later than at sites near the top of the pluton.

According to our model, the Peridotite Zone of the Stillwater Complex more likely cooled within 10-100 kyr. This result is consistent with the convective cooling time which obtained from the top of the layered intrusion (Selkin et al., 2006). This rapid cooling rate may provide evidence that convective cooling was active during cooling of the Peridotite Zone, a mechanism that increases cooling rates by nearly an order of magnitude compared to diffusive cooling (Coogan et al., 2002). Our results thus suggest that the intrusion was not constructed in a strictly sequential stratigraphic order from the base (oldest) to the top (youngest), in agreement with Wall et al. (2018). The parental magma of the Peridotite Zone may have been injected directly into a cooled, crystallized sill. This emplacement mechanism would have enabled rapid convective thermal dissipation (Scoon and Costin, 2018).

\section{CONCLUSIONS}

This paper reports the first systematic attempt at exploring the diffusion-driven chromium isotopic fractionations in minerals of ultramafic cumulates based on elemental and isotopic evidence from the Stillwater Complex. Our major conclusion are as follows:

(1) Chromite grains from the Stillwater Complex have $\delta^{53} \mathrm{Cr}$ values ranging from -0.07 to $-0.23 \%$ o. Evolving chromite $\mathrm{Cr}$ isotopic compositions may be a geochemical indicator of magmatic differentiation. We suggest that magma replenishment and wall rock contamination contributed to the formation of chromitites.

(2) The $\delta^{53} \mathrm{Cr}$ values of olivine and orthopyroxene from the Stillwater Complex show large variations from -0.09 to $0.25 \%$ and from -0.11 to $0.07 \%$, respectively, suggesting disequilibrium inter-mineral isotopic fractionations induced by $\mathrm{Cr}$ diffusion from the crystals to the melt.

(3) The observed Cr elemental zonings and isotopic compositions in our samples suggest that the Peridotite Zone of the Stillwater magma cooled to the Cr diffusive closure temperature within 10 to $100 \mathrm{kyr}$. Chromium elemental and isotopic analyses are thus useful in constraining the cooling times of persistent magma systems.

\section{ACKNOWLEDGEMENTS}

This study was financially supported by the National Natural Science Foundation of China (91755205 and 41772055), the Second Tibetan Plateau Scientific Expedition and Research Program 
(STEP) (2019QZKK0802), the State Key Laboratory of Lithospheric Evolution (201701), and the Youth Innovation Promotion Association, Chinese Academy of Sciences (2016067). Bernard Charlier is a Research Associate of the Belgian Fund for Scientific Research-FNRS. Robert Dennen is acknowledged for extensive editing of the manuscript. This paper has benefited from careful reviews by four anonymous referees and Editor Shi-Chun Huang.

\section{APPENDIX A. SUPPLEMENTARY MATERIAL}

Supplementary data to this article can be found online at https://doi.org/10.1016/j.gca.2019.07.052.

\section{REFERENCES}

Bai Y., Su B. X., Chen C., Yang S. H., Liang Z., Xiao Y., Qin K. Z. and Malaviarachchi S. P. (2017) Base metal mineral segregation and $\mathrm{Fe}-\mathrm{Mg}$ exchange inducing extreme compositions of olivine and chromite from the Xiadong Alaskan-type complex in the southern part of the Central Asian Orogenic Belt. Ore Geol. Rev. 90, 184-192.

Bai Y., Su B. X., Xiao Y., Lenaz D., Asamoah Sakyi P., Liang Z., Chen C. and Yang S. H. (2018) Origin of reverse zoned CrSpinels from the Paleoproterozoic Yanmenguan Mafic-Ultramafic Complex in the North China Craton. Minerals 8, 62-77.

Barnes S. J. (1986) The effect of trapped liquid crystallization on cumulus mineral compositions in layered intrusions. Contrib. Miner. Petrol. 93, 524-531.

Barnes S. J. and Roeder P. L. (2001) The range of spinel compositions in terrestrial mafic and ultramafic rocks. J. Petrol. 42, 2279-2302.

Bonnand P., Parkinson I. J. and Anand M. (2016) Mass-dependent fractionation of stable chromium isotopes in mare basalts: implications for the formation and the differentiation of the Moon. Geochim. Cosmochim. Acta 175, 208-221.

Boudreau A. E. (2016) The Stillwater Complex, Montana-Overview and the significance of volatiles. Mineral. Mag. 80, 585637.

Campbell I. H. and Murck B. W. (1993) Petrology of the G and H chromitite zones in the Mountain View area of the Stillwater Complex, Montana. J. Petrol. 34, 291-316.

Chen L. M., Song X. Y., Zhu X. K., Zhang X. Q., Yu S. Y. and Yi J. N. (2014) Iron isotope fractionation during crystallization and sub-solidus re-equilibration: Constraints from the Baima mafic layered intrusion, SW China. Chem. Geol. 380, 97-109.

Chen L. M., Teng F. Z., Song X. Y., Hu R. Z., Yu S. Y., Zhu D. and Kang J. (2018) Magnesium isotopic evidence for chemical disequilibrium among cumulus minerals in layered mafic intrusion. Earth Planet. Sci. Lett. 487, 74-83.

Chen C., Su B. X., Xiao Y., Sakyi P. A., He X. Q., Pang K. N., Ibrahim U., Erdi A. and Qin L. P. (2019) High-temperature chromium isotope fractionation and its implications: Constraints from Kızıldağ ophiolite, SE Turkey. Lithos 342, 361369 .

Charlier, B., Namur, O., Latypov, R. and Tegner, C. (eds.) (2015) Layered intrusions. Springer Sci., Amsterdam, The Netherlands, $733 \mathrm{p}$.

Collinet M., Charlier B., Namur O., Oeser M., Médard E. and Weyer S. (2017) Crystallization history of enriched shergottites from $\mathrm{Fe}$ and $\mathrm{Mg}$ isotope fractionation in olivine megacrysts. Geochim. Cosmochim. Acta 207, 277-297.

Coogan L. A., Jenkin G. R. and Wilson R. N. (2002) Constraining the cooling rate of the lower oceanic crust: a new approach applied to the Oman ophiolite. Earth Planet. Sci. Lett. 199, $127-146$

Dodson M. H. (1973) Closure temperature in cooling geochronological and petrological systems. Contrib. Miner. Petrol. 40, 259-274.

Drake M. J., Newsom H. E. and Capobianco C. J. (1989) V, Cr, and $\mathrm{Mn}$ in the Earth, Moon, EPB, and SPB and the origin of the Moon: Experimental studies. Geochim. Cosmochim. Acta 53, 2101-2111.

Domeneghetti M. C., McCallum I. S., Schwartz J. M., Camara F., Zema M., McCammon C., and Ganguly J. (2001) Complex Cooling Histories of Lunar Troctolite 76535 and Stillwater Orthoyroxenite SC-936. In Lunar and Planetary Science Conference (Vol. 32).

Farkaš J., Chrastný V., Novák M., Čadkova E., Pašava J., Chakrabarti R., Jacobsen S. B., Ackerman L. and Bullen T. D. (2013) Chromium isotope variations $\left(\delta^{53} \mathrm{Cr}\right)$ in mantle-derived sources and their weathering products: Implications for environmental studies and the evolution of $\delta^{53} \mathrm{Cr}$ in the Earth's mantle over geologic time. Contrib. Miner. Petrol. 123, 74-92.

Foley S. F., Jacob D. E. and O'Neill H. S. C. (2011) Trace element variations in olivine phenocrysts from Ugandan potassic rocks as clues to the chemical characteristics of parental magmas. Contrib. Miner. Petrol. 162, 1-20.

Freer R. (1981) Diffusion in silicate minerals and glasses: A data digest and guide to the Literature. Contrib. Miner. Petrol. 76, 440-454.

Grove T. L., Baker M. B. and Kinzler R. J. (1984) Coupled CaAl$\mathrm{NaSi}$ diffusion in plagioclase feldspar: experiments and applications to cooling rate speedometry. Geochim. Cosmochim. Acta 48, 2113-2121.

Ganguly J. and Tirone M. (1999) Diffusion closure temperature and age of a mineral with arbitrary extent of diffusion: theoretical formulation and applications. Earth Planet. Sci. Lett. 170, 131-140.

Ganguly J. and Tirone M. (2001) Relationship between cooling rate and cooling age of a mineral: theory and applications to meteorites. Meteorit. Planet. Sci. 36, 167-175.

Ganguly J. (2002) Diffusion kinetics in minerals: Principles and applications to tectono-metamorphic processes. EMU Notes Mineral. 4, 271-309.

Ganguly J., Ito M. and Zhang X. (2007) $\mathrm{Cr}$ diffusion in orthopyroxene: Experimental determination, ${ }^{53} \mathrm{Mn}-{ }^{53} \mathrm{Cr}$ thermochronology, and planetary applications. Geochim. Cosmochim. Acta 71, 3915-3925.

Guotana J. M. R., Payot B. D., Dimalanta C. B., Ramos N. T., Faustino-Eslava D. V., Queaño K. L. and Yumul, Jr, G. P. (2018) Petrological and geochemical characteristics of the Samar Ophiolite ultramafic section: Implications on the origins of the ophiolites in Samar and Leyte islands, Philippines. Int. Geol. Rev. 60, 401-417.

Griffin W. L. (2008) GLITTER: data reduction software for laser ablation ICP-MS. Laser Ablation ICP-MS in the Earth Sciences: Current practices and outstanding issues, pp. 308-311.

Han R., Qin L., Brown S. T., Christensen J. N. and Beller H. R. (2012) Differential isotopic fractionation during Cr (VI) reduction by an aquifer-derived bacterium under aerobic versus denitrifying conditions. Appl. Environ. Microbiol. 78, 24622464.

Helz R. T. (1995) The Stillwater Complex, Montana: A subvolcanic magma chamber? Am. Mineral. 80, 1343-1346.

Herzberg C. and O'hara M. J. (2002) Plume-associated ultramafic magmas of Phanerozoic age. J. Petrol. 43, 1857-1883.

Hess H. H. and Smith J. R. (1960) Stillwater igneous complex, Montana a quantitative. Geol. Society Am., Memoir 80, 230 p. 
Hess G. B. (1972) Heat and mass transport during crystallization of the Stillwater igneous complex. Geol. Soc. Am. Memoir 132, 503-520.

Huang F., Chakraborty P., Lundstrom C. C., Holmden C., Glessner J. J. G., Kieffer S. W. and Lesher C. E. (2010) Isotope fractionation in silicate melts by thermal diffusion. Nature 464, 396.

Irvine T. N. (1970) Heat transfer during solidification of layered intrusions. I. Sheets and sills. Can. J. Earth Sci. 7, 1031-1061.

Ito M. and Ganguly J. (2006) Diffusion kinetics of $\mathrm{Cr}$ in olivine and ${ }^{53} \mathrm{Mn}-{ }^{53} \mathrm{Cr}$ thermochronology of early solar system objects. Geochim. Cosmochim. Acta 70, 799-809.

Jackson E. D. (1961) Primary textures and mineral associations in the Ultramafic Zone of the Stillwater Complex, Montana. U.S. Geol. Survey Professional Paper 358, 106 p.

Jenkins M. C. and Mungall J. E. (2018) Genesis of the Peridotite Zone, Stillwater Complex, Montana, USA. J. Petrol. 59, 21572189.

Jollands M. C., O'Neill H. S. C., Van Orman J., Berry A. J., Hermann J., Newville M. and Lanzirotti A. (2017) Substitution and diffusion of $\mathrm{Cr}^{2+}$ and $\mathrm{Cr}^{3+}$ in synthetic forsterite and natural olivine at $1200-1500^{\circ} \mathrm{C}$ and 1 bar. Geochim. Cosmochim. Acta 220, 407-428.

Kaufmann F. E., Vukmanovic Z., Holness M. B. and Hecht L. (2018) Orthopyroxene oikocrysts in the MG1 chromitite layer of the Bushveld Complex: Implications for cumulate formation and recrystallisation. Contrib. Miner. Petrol. 173, 1-17.

Kennedy A. K., Lofgren G. E. and Wasserburg G. J. (1993) An experimental study of trace element partitioning between olivine, orthopyroxene and melt in chondrules: equilibrium values and kinetic effects. Earth Planet. Sci. Lett. 115, 177-195.

Labotka T. C. and Kath R. L. (2001) Petrogenesis of the contactmetamorphic rocks beneath the Stillwater Complex, Montana. Geol. Soc. Am. Bull. 113, 1312-1323.

Lesher C. E. and Walker D. (1986) Solution properties of silicate liquids from thermal diffusion experiments. Geochim. Cosmochim. Acta 50, 1397-1411.

Liu P. P., Zhou M. F., Luais B., Cividini D. and Rollion-Bard C. (2014) Disequilibrium iron isotopic fractionation during the high-temperature magmatic differentiation of the Baima Fe-Ti oxide-bearing mafic intrusion, SW China. Earth Planet. Sci. Lett. 399, 21-29.

Lugmair G. W. and Shukolyukov A. (1998) Early solar system timescales according to ${ }^{53} \mathrm{Mn}-{ }^{53} \mathrm{Cr}$ systematics. Geochim. Cosmochim. Acta 62, 2863-2886.

Maier W. D., Barnes S. J. and Groves D. I. (2012) The Bushveld Complex, South Africa: Formation of platinum-palladium, chrome- and vanadium-rich layers via hydrodynamic sorting of a mobilized cumulate slurry in a large, relatively slowly cooling, subsiding magma chamber. Miner. Dep. 48, 1-56.

Manoochehri S. and Schmidt M. W. (2014) Settling and compaction of chromite cumulates employing a centrifuging piston cylinder and application to layered mafic intrusions. Contrib. Miner. Petrol. 168, 1091.

McCallum I. S. (1996) The Stillwater complex. Dev. Petrol. 15, 441-483.

McCallum I. S., Domeneghetti M. C., Schwartz J. M., Mullen E. K., Zema M., Cámara F., McCammon C. and Ganguly J. (2006) Cooling history of lunar Mg-suite gabbronorite 76255, troctolite 76535 and Stillwater pyroxenite SC-936: The record in exsolution and ordering in pyroxenes. Geochim. Cosmochim. Acta 70, 6068-6078.

Milman-Barris M. S., Beckett J. R., Baker M. B., Hofmann A. E., Morgan Z., Crowley M. R., Vielzeuf D. and Stolper E. (2008) Zoning of phosphorus in igneous olivine. Contrib. Miner. Petrol. 155, 739-765.
Moynier F., Yin Q. Z. and Schauble E. (2011) Isotopic evidence of Cr partitioning into Earth's core. Science 331, 1417-1420.

Oeser M., Dohmen R., Horn I., Schuth S. and Weyer S. (2015) Processes and time scales of magmatic evolution as revealed by $\mathrm{Fe}-\mathrm{Mg}$ chemical and isotopic zoning in natural olivines. Geochim. Cosmochim. Acta 154, 130-150.

Ohtani E., Kawabe I., Moriyama J. and Nagata Y. (1989) Partitioning of elements between majorite garnet and melt and implications for petrogenesis of komatiite. Contrib. Miner. Petrol. 103, 263-269.

Page N. J. (1979) Stillwater Complex, Montana: Structure, mineralogy, and petrology of the Basal Zone with emphasis on the occurrence of sulfides. Department Interior, Geol. Survey 1038, 67.

Papike J. J., Karner J. M. and Shearer C. K. (2005) Comparative planetary mineralogy: Valence state partitioning of $\mathrm{Cr}$, $\mathrm{Fe}, \mathrm{Ti}$, and $\mathrm{V}$ among crystallographic sites in olivine, pyroxene, and spinel from planetary basalts. Am. Mineral. 90, 277-290.

Polyakov V. B. and Mineev S. D. (2000) The use of Mössbauer spectroscopy in stable isotope geochemistry. Geochim. Cosmochim. Acta 64, 849-865.

Polyakov V. B., Clayton R. N., Horita J. and Mineev S. D. (2007) Equilibrium iron isotope fractionation factors of minerals: reevaluation from the data of nuclear inelastic resonant X-ray scattering and Mössbauer spectroscopy. Geochim. Cosmochim. Acta 71, 3833-3846.

Posner E. S., Ganguly J. and Hervig R. (2016) Diffusion kinetics of $\mathrm{Cr}$ in spinel: Experimental studies and implications for ${ }^{53}$ $\mathrm{Mn}-{ }^{53} \mathrm{Cr}$ cosmochronology. Geochim. Cosmochim. Acta 175, 20-35.

Pre $\beta$ S., Wirr G., Seck H. A., Eonov D. and Kovalenko V. I. (1986) Spinel peridotite xenoliths from the Tariat Depression, Mongolia. I: Major element chemistry and mineralogy of a primitive mantle xenolith suite. Geochim. Cosmochim. Acta 50, 25872599.

Prelević D., Jacob D. E. and Foley S. F. (2013) Recycling plus: A new recipe for the formation of Alpine-Himalayan orogenic mantle lithosphere. Earth Planet. Sci. Lett. 362, 187-197.

Qin L. and Wang X. (2017) Chromium isotope geochemistry. Rev. Mineral. Geochem. 82, 379-414.

Qin L., Alexander C. M. D., Carlson R. W., Horan M. F. and Yokoyama T. (2010) Contributors to chromium isotope variation of meteorites. Geochim. Cosmochim. Acta 74, 1122-1145.

Raedeke L. D. and McCallum I. S. (1984) Investigations in the Stillwater complex: Part II. Petrology and petrogenesis of the ultramafic series. J. Petrol. 25, 395-420.

Richter F. M., Liang Y. and Davis A. M. (1999) Isotope fractionation by diffusion in molten oxides. Geochim. Cosmochim. Acta 63, 2853-2861.

Richter F. M., Davis A. M., Depaolo D. J. and Watson E. B. (2003) Isotope fractionation by chemical diffusion between molten basalt and rhyolite. Geochim. Cosmochim. Acta 67, 3905-3923.

Richter F. M., Watson E. B., Mendybaev R., Dauphas N., Georg B., Watkins J. and Valley J. (2009) Isotopic fractionation of the major elements of molten basalt by chemical and thermal diffusion. Geochim. Cosmochim. Acta 73, 4250-4263.

Roeder P. L., Campbell I. H. and Jamieson H. E. (1979) A reevaluation of the olivine-spinel geothermometer. Contrib. Miner. Petrol. 68, 325.

Scoon R. N. and Costin G. (2018) Chemistry, morphology and origin of magmatic-reaction chromite stringers associated with anorthosite in the Upper Critical Zone at Winnaarshoek, Eastern Limb of the Bushveld Complex. J. Petrol. 59, 15511578 . 
Sio C. K., Roskosz M., Dauphas N., Bennett N. R., Mock T. and Shahar A. (2018) The isotope effect for Mg-Fe interdiffusion in olivine and its dependence on crystal orientation, composition and temperature. Geochim. Cosmochim. Acta 239, 463-480.

Schiller M., Van Kooten E., Holst J. C., Olsen M. B. and Bizzarro M. (2014) Precise measurement of chromium isotopes by MCICP-MS. J. Anal. At. Spectrom. 29, 1406-1416.

Schoenberg R., Zink S., Staubwasser M. and Von Blanckenburg F. (2008) The stable Cr isotope inventory of solid Earth reservoirs determined by double spike MC-ICP-MS. Chem. Geol. 249, 294-306.

Schoenberg R., Merdian A., Holmden C., Kleinhanns I. C., Haßler K., Wille M. and Reitter E. (2016) The stable Cr isotopic compositions of chondrites and silicate planetary reservoirs. Geochim. Cosmochim. Acta 183, 14-30.

Shen J., Liu J., Qin L., Wang S. J., Li S., Xia J., Ke S. and Yang J. (2015) Chromium isotope signature during continental crust subduction recorded in metamorphic rocks. Geochem. Geophys. Geosyst. 16, 3840-3854.

Shen J., Qin L., Fang Z., Zhang Y., Liu J., Liu W., Wang F., Xiao Y., Yu H. and Wei S. (2018) High-temperature inter-mineral Cr isotope fractionation: A comparison of ionic model predictions and experimental investigations of mantle xenoliths from the North China Craton. Earth Planet. Sci. Lett. 499, 278-290.

Spandler C., Mavrogenes J. and Arculus R. (2005) Origin of chromitites in layered intrusions: Evidence from chromitehosted melt inclusions from the Stillwater Complex. Geology 33, 893-896.

Suzuki A. M., Yasuda A. and Ozawa K. (2008) Cr and Al diffusion in chromite spinel: Experimental determination and its implication for diffusion creep. Phys. Chem. Miner. 35, 433.

Selkin P. A., Gee J. S., Tauxe L., Meurer W. P. and Newell A. J. (2000) The effect of remanence anisotropy on paleointensity estimates: a case study from the Archean Stillwater Complex. Earth Planet. Sci. Lett. 183, 403-416.
Selkin P. A., Gee J. S., Meurer W. P. and Hemming S. R. (2006) Paleointensity record from the $2.7 \mathrm{Ga}$ Stillwater complex, Montana. Geochem. Geophys. Geosyst. 9, 1-9.

Talkington R. W. and Lipin B. R. (1986) Platinum-group minerals in chromite seams of the Stillwater Complex, Montana. Econ. Geol. 8, 1179-1186.

Teng F. Z., Dauphas N., Helz R. T., Gao S. and Huang S. (2011) Diffusion-driven magnesium and iron isotope fractionation in Hawaiian olivine. Earth Planet. Sci. Lett. 308, 317-324.

Wall C. J., Scoates J. S., Weis D., Friedman R. M., Amini M. and Meurer W. P. (2018) The Stillwater Complex: Integrating Zircon Geochronological and Geochemical Constraints on the Age, Emplacement History and Crystallization of a Large, Open-System Layered Intrusion. J. Petrol. 59, 153-190.

Wu S., Karius V., Schmidt B. C., Simon K. and Wörner G. (2018) Comparison of Ultrafine Powder Pellet and Flux-free Fusion Glass for Bulk Analysis of Granitoids by Laser AblationInductively Coupled Plasma-Mass Spectrometry. Geostand. Geoanal. Res. 42, 575-591.

Xia J., Qin L., Shen J., Carlson R. W., Ionov D. A. and Mock T. D. (2017) Chromium isotope heterogeneity in the mantle. Earth Planet. Sci. Lett. 464, 103-115.

Xiao Y., Teng F. Z., Su B. X., Hu Y., Zhou M. F., Zhu B., Shi R. D., Huang Q. S., Gong X. H. and He Y. S. (2016) Iron and magnesium isotopic constraints on the origin of chemical heterogeneity in podiform chromitite from the Luobusa ophiolite, Tibet. Geochem. Geophys. Geosyst. 17, 940-953.

Yang K. and Seccombe P. K. (1993) Chemical variation of chromite in the ultramafic cumulates of the Great Serpentinite Belt, Upper Bingara to Doonba, New South Wales, Australia. Can. Mineral. 31, 75-87. 